

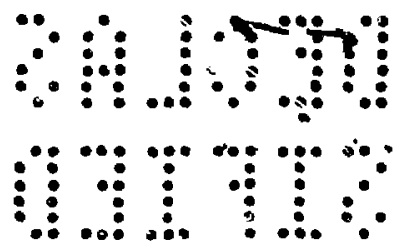

This report was prepared as an account of work sporisored by the United Strtes Government. Neither the United States nor the United States Atomic Energy Commission, nor any of their employees, nor any of their contractors, subcontrectors, or their employees, makes any warranty, express or im. plied, of assumes any legal liability or responsibility for the accuracy, com. pleteness or usefulness of any information, apperatus, product or process dis. closed, or represents that its use would not infringe privateiy owned rights.

Classified by John W. McDonald

ISD-6 Classification Officer

Excluded from automatic downgrading or declassification by Sec. 5B2 of Executive Order 11652. 
This document consists of 29 pages

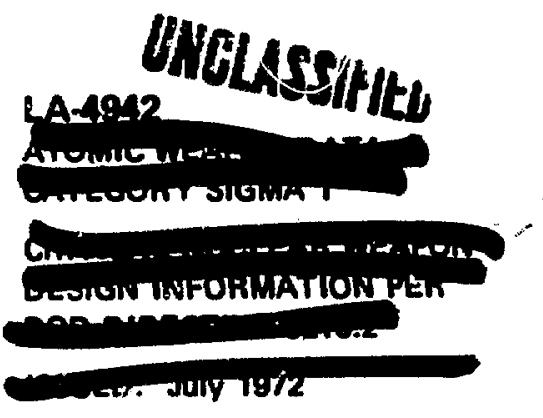

No. $: ?$ of 40 copies, Series $A$

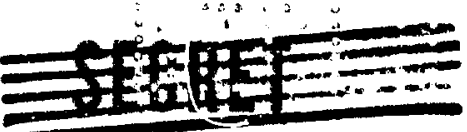

romelation

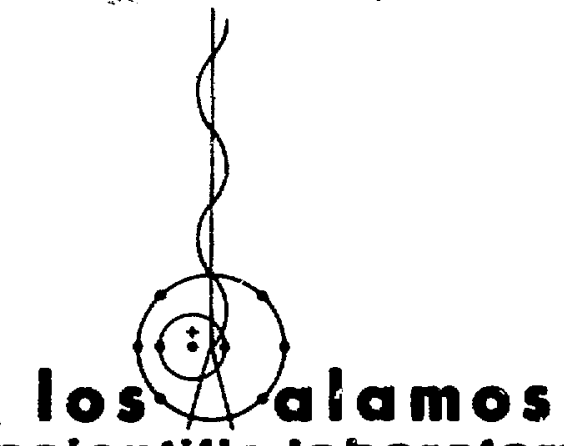

ocionitic laboratory

of the University of California

IOS ALAMOS. NEW MEXICO ITSA4

$! \quad$

\section{Hugoniof Equations of State}

\section{of $L i^{6} \mathrm{H}, L i^{6} \mathrm{D}, \mathrm{Li}^{\mathrm{n}} \mathrm{H}$, and $\mathrm{Li}{ }^{n} \mathrm{D}(\mathrm{U})$}

by

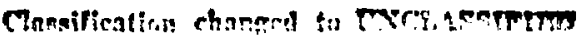

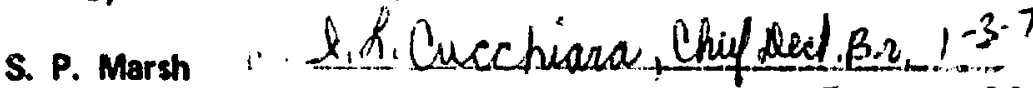

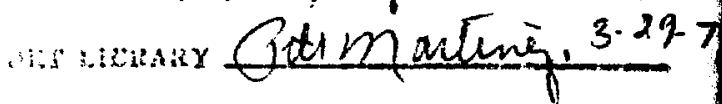

_UNITED STATES

ato herjency commission

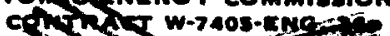

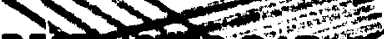

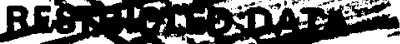

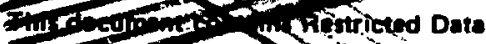

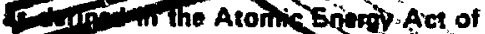

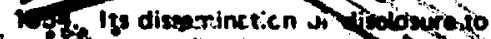

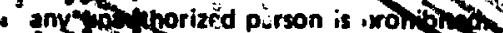

WHELASEIFEA I

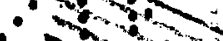

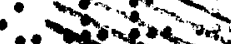


USAEC, Hodquarters L.ibrery, Reports Section, Weshington, D. C.

Menager, ALO, Alouquerqy. Now Mexico

Lenrence Lhermore Laboratory, Livermore, California

Sandis Corporation, Albuquerque, New Mexico

Military Lisison Committes, Washington, D. C.

Director, Dofense Reseerch and Engineering, Washington, D. C.

Headquarters, Defense Nuclear Agency, Washington, D. C.

Dofense Nucteer Agoncy Fietd Command, Kirtland AFB, Now Moxico

Commending Gemeral, Army Combat Developments Command, Fort Betvoir, Virginia

Commanding General, Army Materiel Command, Weahington, D. C.

DCSFoperations, Army, Woghington, D. C.

Chief, R\&D, Army, Wreshington, D. C.

Neval Ordnance Systems Commend, Washington, D. C.

Chiof of Noval Operations (OP.75), Wathington, D. C.

DCS/Reserch and Devalopment, Headquerters, USAF, Weahington, D. C.

Director, Air Force Weapons Loboratory, Kintiand Air Force Base, Now Moxico

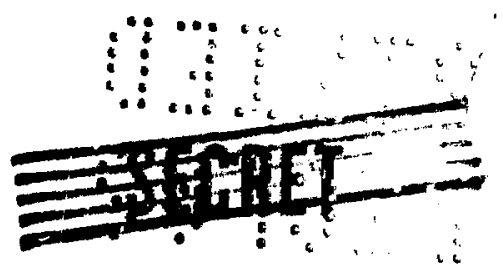




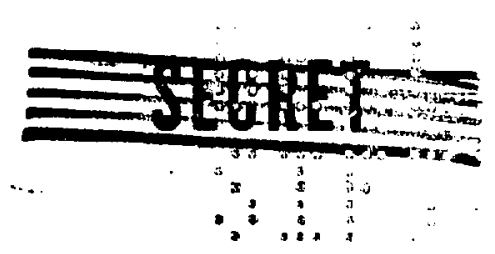

NOTHCE

This report was prepued as an cccount of wotk This report was propas sen Govumment. Noither sponsorad by the Unis Snited States Atomic Eners the United States nor the Unitis statoyeet, not any of Cominiation, nor any of ther employ thet nomplo ; ces: theit contractors, subcontrseters, os

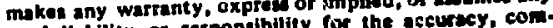
legal linbility of responsibility for the accuracy, cons plotenise of usefulsese of any injormaticn, apptratus, product of procues diselcied, or represents that is we would not infringe privelely owned rights.

HUGONIOT EQUATIONS OF STATE OF Li ${ }^{6} \mathrm{H}, \operatorname{Li}^{6} \mathrm{D}, \mathrm{Li}^{a} \mathrm{H}$, AND Li $i^{\mathrm{a}} \mathrm{D}$

by

S. P. Marsh

\section{ABSTRACT (SRD)}

An experimental value of $1.08 \mathrm{~cm}^{3} / \mathrm{g}$ for $(\partial \mathrm{E} / \partial \mathrm{P})_{4}$ was determined from the Hugoniot data on pressed $\mathrm{Li}^{8} \mathrm{D}$ of various porosities

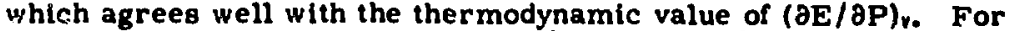
each of the isotopic combinations $L \mathrm{I}^{6} \mathrm{H}, \mathrm{LI} \mathrm{I}^{4} \mathrm{H}, \mathrm{Ll} \mathrm{I}^{6} \mathrm{D}$, and $\mathrm{L} \mathrm{I}^{\mathrm{A}} \mathrm{D}$ crystal-density Hugoniots and equations of state were calculated from Hugoniot data on pressed material having porosity of $5 \%$ or less and

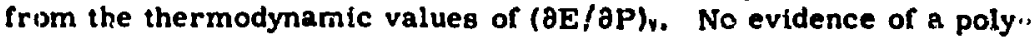
misphic transition was observed.

Ultrasonic measurements of longltudinal and shear-waye velocities in these materials pressed to near crystal density were olst: ined, and the isotroplc elastic moduli were calculated. In addition, elagtic constants were ditermined for crystals of $\mathrm{Li}^{\mathrm{k}} \mathrm{H}$, $I f^{2} \mathrm{H}$, and $\mathrm{LI}^{2} \mathrm{D}$.

\section{INTRODUC'TION}

Hugoniot data for $\mathrm{LI} H$ and $\mathrm{LI} \mathrm{I}^{\mathrm{N}} \mathrm{D}$ have been reported by a number of investigators, In 1954 , Walsh" atudied pressed Li"H to pressures of 160 kbar. Hle also reported data ${ }^{2}$ on single crystals of $L i^{*}\left(\left[b_{0},{ }_{0} H_{0}, D_{0}\right)\right.$ shocked to pressures above 500 kbar. In 1954, Burton and Landeen ${ }^{3}$ obiained iwo Hulfoniot clata points on pressed Li"H at pressures above 709 kbar using a spherically convergent driver system. In 1965, Kusubov ${ }^{4}$ obtained data on pressed $L i^{d} H, L f^{19} D, L i^{7} H$, and $L i^{7} \mathrm{D}$ all presiaures up $10500 \mathrm{kbar}$, as well as longitudinal and shear-wave velocitles for each matcrial. in 1969. May 5 and Guess ${ }^{6}$ reported Hugoniol data below $200 \mathrm{kbar}$, obtained using quartz-gage detectors on pressed Li ${ }^{*}$ H. Guess also reported longitudinal and shear-wave velocities in this same material.
In this endeavor, we have determined the Hugoniots of $\mathrm{Li}^{6} \mathrm{D}$ pressed to near crystal density and at porosities of approximately $5,8,17,28$, 36 , and 44\%. The wide range of initial densities enabled us to determine the average values of the Grüneisen gamma, $\gamma \approx V(\partial P / \partial E)_{v}$. These values are compared $w$ ith the Grïneisen ratio determined from thermodynamic measurements at standard iemperature and pressure. The Hugontots of the

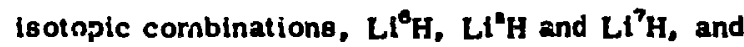
Li'D for pressed samples with an inttial $5 \%$ porosity have also been determined. Further, we have ohtained Hugoniot data on a few crystals of $\mathrm{Li}^{2} \mathrm{H}$ and $L_{1}{ }^{7} D$, and have determined elastic constants for crystals of $L i^{*} H, L I^{7} H$, and $L I^{7} D$. Material

The crystals used in these experitments

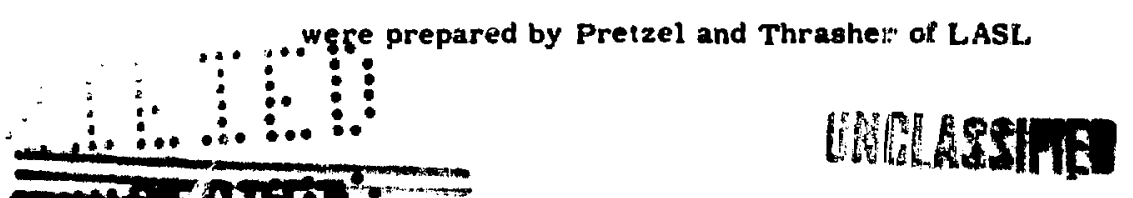




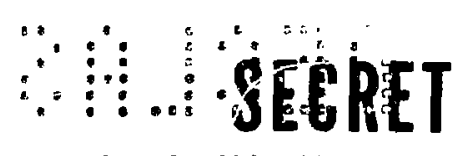

Group CMB -3. All pressed matenials ard their chemical analysis and densities were obtained from $\mathrm{Y}-12$ at Oak Ridge. The $\mathrm{Li}^{\mathrm{B}}$ had a composition of 95.5 at. $\% \mathrm{Li}^{6}$ and 4.5 at. $\% \mathrm{Li}^{7}$; the normal $\mathrm{Li}^{\mathrm{n}}$ was 7.5 at. $\% \mathrm{Li}^{\mathrm{B}}$ and 92.5 at. $\% \mathrm{Li}^{7}$; and the $\mathrm{Li}^{7}$ was 100 at. $\% \mathrm{Li}^{7}$. The is otopic purity of the hydrogen and deuterium was above 99 at. $\%$. The densities of the four pure isotopic combinations were calculated from the lattice parameters reported by Anderson et: al. 7 We used these iensities to compute the value of the crystal densities of the particular isotopic compositions used here. The Oak Ridge analysis provided an estimate of the oxygen in our samples, and we calculated their ideal or crystal density by mixing 2 wt $\%$ of the hydroxide or deuteroxide using the densities that Vier $^{8}$ reported and the density for oxygen free materials. These densities were used to determine the porusity and are listed in Table $I$ the end of this report.

\section{ELASTIC CONSTANTS IN LIT HIUM HYDRIDE}

\section{f. ID LITHTUM DEUTERIDE}

Elastic-wave velocities were determined ultrazonically using a pulse-echo method ${ }^{9}$ on pressed isotropic samples at near crystal density for ali isotopic compositions. The longitudinal and shear-wave velocities $\left(V_{L}\right.$ and $\left.V_{S}\right)$ were measured, and the bull: sound velocity $\left(C_{b}\right)$ was calculated from the expression

$$
C_{v}^{2} * v_{L}^{2}-4 / 3 v_{s}^{2} \text {. }
$$

Table II lists the results of sound-velority measurements on the various isotopic combinations of lithium hydride at near crystal density and at approximately 5\% porosity. The bulk modulus $\left(B_{3}\right)$, shesur modulus $(\mu)$, Young's modulus $(Y)$, longitudinal modulus $\left(B_{L}\right)$, and Poisson's ratio $(\sigma)$ are algo listed.

Using the same apparatus used for making pulse-echo sound-velocity measurements in pressed specimens, we determined the sound velocities in $\mathrm{Li}^{7} \mathrm{H}_{z} \mathrm{Li}^{7} \mathrm{H}$, and $\mathrm{Li}{ }^{\top} \mathrm{D}$ crystals. Because of the difficuity in seeing the arrival tirfe ...
If the echo signals, we used a different method of measurement in which we observed the arrival times through several different thicknesses of sample and obtained the velocity from the derivative of the resulting $x-t$ data. Table III shows the results of these measurements for both the longitudinal and shear-wave velocities in the [100] direction and the longitudinal and two shear-wave velocities in the $[110]$ direct $n$. The errors in the longitudinal and shear-wave velocities are 0.5 and $1.0 \%$, respectively. We obtained the elastic constants using the following set of equations which involve only the velocities in the [100] direction and the bulk sound velocities $\left(C_{0}\right)$ deduced from sound-velocity measurements on pressed isotropic samples.

$$
\begin{aligned}
& c_{21}=\rho V_{L}^{2}[100], \\
& c_{n}=\rho V_{3}^{2}[100], \\
& c_{22}=\frac{3 \rho C_{2}^{2}-\rho V_{L}^{2}[100] .}{2} .
\end{aligned}
$$

We compared the measured velocitise in the [110] direction with the calculated velocities in that direction to check the derived elastic constants. The expressions used to calculate these velocities were

$$
\begin{aligned}
& V_{b}[110]=\sqrt{\frac{c_{11}+c_{29}+2 c_{46}}{2 p}}, \\
& V_{2 s}[110]=\sqrt{\frac{c \mu}{\rho}} \quad \text { (for particle } \\
& \text { motion in the } \\
& V_{25}[110]=\sqrt{\frac{C_{11}-C_{29}}{2 p}}
\end{aligned}
$$

The measurec and calculated velocities in this direction differ by several percent, a greater amount than would be anticipated from the error in the eiastic constants, which is 1, 2, and $20 \%$ in $c_{11}, c_{46}$, and $c_{12}$, respectively. The reason for this discrepancy is not understood. Another disturbing feature observed in this table is that the $c_{11}$ and $c_{4}$ values for $L i^{7} D$ are lower than the corresponding values for $L^{n}{ }^{n} \mathrm{H}$ and $\mathrm{Li}^{7} \mathrm{H}$, We

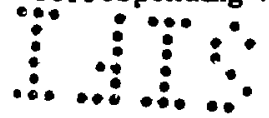


feel that because the lattice spacing is smaller for $\mathrm{Li}^{7} \mathrm{D}$, the zero-point energy is also lower and, consequently, the elastic constants should be higher. We can give no resson for tinis apparent reversal. The differences in the elastic constants for $\mathrm{Li}^{\mathrm{D}} \mathrm{H}$ and $\mathrm{Li} \mathrm{i}^{\mathrm{H}} \mathrm{H}$ are not statistically significant.

The elastic moduli in Table II show a distinct relationship to isotopic composition. The bulk modulus, shear inodulus, Young's modulus, and longitudinal modulus agree for $\mathrm{Li}^{6} \mathrm{H}$ and $\mathrm{Li}{ }^{\mathrm{D}} \mathrm{H}$ and are $3 \%$ smaller than the elastic muduli of the deuterides, which are also in agreement. In this case, the elastic moduli are consistent with the zero-point energy assumption mentioned above. SHOCK-WAVE EXPERIMENTS

We used Walsh and Christian's shockimpedance match technique ${ }^{10}$ with 2024 Al as a standard, and the optical fiash-gap method to determine the Hugoniots. The shock velocities in both the standerd and lithium hydride sample/3 were measured with a sweeping-image camera. Having the equation of state of the standard and the shock velocities in botk the standard and lithiurn hydride samples permits determination of the pressure and particle velocity. A linear shock -particle velocity Hugoniot,

$$
\mathrm{U}_{3}=5.328+1.338 \mathrm{U} \text {. (in units of } \mathrm{km} / \mathrm{sec} \text { ), }
$$

and a constant value of

$$
\rho \gamma=5.57 \mathrm{~g} / \mathrm{cm}^{3}
$$

(where $\rho$ and $\gamma$ are the density and Grürieisen parameter) specify the efuation of state of the standard required for the impedance-match solution.

We determined the density and internal energy of the shocked materials using the Rankine-Hugoniot relations. Tables IV - XIII show the experimental data and derived Hugoniot parameters.

\section{ANALYSIS AND INTERPRETATION}

Performing shock-wave experiments on materials of different porosities allows examination of different pressure-energy regions becausa. the graater tre initial volume, the greater the pressure and internal energy at the same final density. This can be seen in Fig. 1 where the pressure-density shock-wave data for the $\mathrm{Li}^{\theta} \mathrm{D}$ are plotted. The curve in this figure is a linear fit of the $U_{g}-U_{p}$ data for the high-density samples, presented in Fig. 2.

An average $(\partial \mathrm{E} / \partial \mathrm{P})_{\mathrm{v}}$ value can be determined for each experimental point of the low initial-density material by differencing its pressure and energy with the pressure and energy calculated at the same density from the fit of the

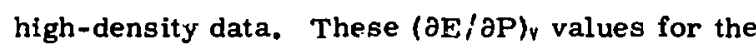
five most porous materials are shown in Fig. 3. The $(\partial E / \partial P)_{y}$ values calculatad from porousmaterial data having small energy and pressure offsets from the high-density Hugoniot (which includes all the low-pressure data) have large errors; consequently, we show only $(\partial E / \partial P)_{V}$ values for which $\Delta P$ was larger than $15 \mathrm{kbar}$. The average $: \partial E / \partial P)_{4}$ value determined from these experiments is $1.08 \mathrm{~cm} / \mathrm{g}$, and within experimental error it does not appear to be a function of density or pressure.

We caiculated the Grineisen $\gamma^{\prime} s$ at standard conditions, along $w$ ith the corresponding $(\partial E / \partial P)_{v}$ values, using the expressions

$$
\gamma=\frac{\beta C_{b}^{2}}{c_{\theta}}, \gamma=V_{0} /(\partial E / \partial P)_{v} .
$$

We obtained the values of $\beta$ (volume coefficient of thermal expansion at $25^{\circ} \mathrm{C}$ ) for all isotopic compositions by interpolating the thermal-expansion data of Anderson et al. ${ }^{7}$ (Fig. 4) and used them for our isotopic compositions. The resulting $\mathrm{Li}^{7} \mathrm{H}$ value $\left(31.0 \times 10^{-6} /{ }^{a} \mathrm{~K}\right)$ is somewhat lower than that obtained by a number of other investigators, $11-14$ but it agrees with the compilation by Goldsmith et al. ${ }^{15}$ for $\mathrm{Li}^{\mathrm{B}} \mathrm{H}$ at $25^{\circ} \mathrm{C}$. The $6.682-\mathrm{cal} / \mathrm{mol}{ }^{\circ} \mathrm{K}$ value of $\mathrm{c}_{\text {, }}$ (specific heat at $\mathrm{a}$ constant pressure) for $\mathrm{Li}^{\mathrm{D}} \mathrm{H}$ was obtained from the JANAF Tables. ${ }^{i 6}$ This value was used for all isotopic compositions. The specific volume ( $\left.V_{0}\right)$ 


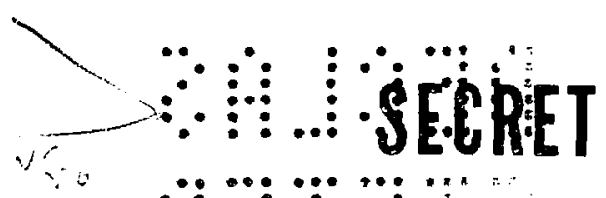

anc bulk sound velocities are those I (for chemically pure compounds) and Table II. A summary of these values and the resulting. values of $\gamma$ and $(\partial \mathrm{E} / \partial \mathrm{P})_{\gamma}$ is given in Table XIV. The experimental $\left(1.08-\mathrm{cm}^{3} / \mathrm{g}\right)$ value of $(\partial E / \partial P)_{v}$ for $\mathrm{Li}^{6} \mathrm{D}$ agrees well with the thermodynamic value of $1.13 \mathrm{~cm}^{3} / \mathrm{g}$ shown in this table.

The values of $(\partial E / \partial P)_{v}$ in Table XIV were used to transform the Hugoniot data obtained on the porous samples to pressures and energies corresponding to samples at crystal density. ${ }^{9}$ These transformations are made at constant volume. The recentered Hugoniot data and a linear least-squares fit of the $U_{s}-U_{p}$ points are shown in the $U_{3}-U_{P}$ plane and the $P-\rho$ plane in Fige, 5-12 along with the bulk sound velocities with which the intercepts should agree if there are no transitions. The least-squares fits summarized in Table $X V$ were determined only from points having $U_{p}>0.9 \mathrm{~km} / \mathrm{sec}$. We chose this lower particle-velocity limit to avoid the extreme sensitivity of the transformed $U_{5}-U_{p}$ points to small errors in the original data at low pressure. The bulk sound velocities and the Hagoniot intercepts agree well.

From these Hugoniots and the thermodynamic data in Table XIV, one can determine a complete equation of state for each material. 9 Tables XVI-XTX list the thermodynamic parameters on the Hugoniot, the foot of the release isentrope, and the isotherms at room temperature and at $0^{\circ} \mathrm{K}$. The zero-pressure parameters used in calculating these loci are summarized at the head of each table.

In Figs. 1.3-16 our Hugoniot results are compared with the results of other investigators studying similar isotopic compositions. We converted isothermal compression data to Hugoniot shock velocity-particle velocity points using the equations of state shown in Tables XVI-XIX. Stevens and Lilley's results 17 generally show less conpressibility than ours, and Kusubov's resyng 4 . compressibility. Burton and Landeen's highpressure data ${ }^{3}$ for $\mathrm{Li}^{\mathrm{n}} \mathrm{H}$ are also rnore compressible than our extrapolated Hugoniot. TRANSITION IN LITHIUM HYDRIDE AND

\section{LITHIUM DEUTERIDE}

Several investigators have postulated a transition from the $\mathrm{NaCl}$ to the $\mathrm{CsCl}$ structure in lithium hydride, but no transiormation has been observed. Schumacher, ${ }^{18}$ using two different Born-Mayer potentials for lithium hydride, calculates a transition at 3 to 4 kbar involving a volume change of about $0.4 \%$. Voroncv et al. 19 showed experimentally that there if a linear relationship of compiessibility to pressure up to 20 kbar which did not fit the aimple Born model. Using Schumacher's potential function, he predicted that the transition should occur at $140 \mathrm{kbar}$ with a volume change of $14 \%$. Other experiment ers $^{20,21}$ have also examined lithium hydride and have found no evidence for a transformation. Stephens and Lilley ${ }^{17}$ determined the isothermal compressibility of $\mathrm{Li}^{6} \mathrm{H}, \mathrm{Li}^{6} \mathrm{D}, \mathrm{Li}^{7} \mathrm{H}$, and $\mathrm{Li}{ }^{7} \mathrm{D}$ $p$ to $40 \mathrm{kbar}$ and $f$ :und that their data fit the simple Born-Mayer model, but observed no transition.

There is no evidence of a transition for any of the isotopic combinations in the pressure region (60 to $450 \mathrm{kbar}$ ) that we investigated. The data for the low-porosity $\mathrm{Li}^{6} \mathrm{D}$ are particularly important, and aithough the low-pressure data have considerable scatter there is no evidence of a kink indicative of a transition in the $U_{g}-U_{p}$ curve. It is somewhat more difficult to detect transitions in the more porous samples, however. Although we see no evidence for a transition in our data, it may possibly be present but have ton small a volume change to be observed as a discontinuity in the shock-wave data.

\section{REFERENCES}

1. Jo M. Walsh, LASL internal document (June 1954).

2. J. M. Walsh, LASL internal document Nogember 1956).

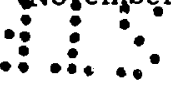


3. B. L. Eurion and S. A. Landeen, LASL interna' Progress Report, August 16, 1954 , to September 15, 1954.

4. A. Kusubov, "Dynamic Equation of State of $\mathrm{Li}^{6} \mathrm{H}$ and $\mathrm{Li}^{6} \mathrm{D},{ }^{\prime}$ LRL report COTMA 67-9, STN \# 97 (May 14, 1965).

5. R. P. May, "High Pressure Shosk Wave Study of Lithium Hydı ile ( $\left.\mathrm{Li}^{7} \mathrm{H}\right)$ in the Solid and Distended States, "Sandia Laboratories report SC-DR-68-875 (February 1969).

€. T. R. Guess, "Low-Pressure Equation of State Studies on Lithium Hydride $\left(\mathrm{Li}^{7} \mathrm{H}\right)$ in the Distended Sates, "Sandia Laboratories report SC-DR-69-762 (November 1969).

7. J. L. Anderson, J. Nasise, K. Philipoon, and F. E. Pretzel, J. Phy :. Chem. Solids 31, $613(1970)$.

8. D. T. Vier, "Calculated Density' of Lithium Hydride and Lithium Hydro:ide for Various Isotopic Compositions," Los Alamos Scientific Laboratory report LAMS -3047 (March 1964).

9. R. G. McQueen, S. P. Marsh, J. W. Taylor, J. N. Fritz, and W. J. Carter, "The Equaticn of State of Solids from Shock Wave Studies," in High-Velocity Impact Fhenomena, R. Kinslov: Ed, (Academic Press, New York, 1970).

10. J. M. Walsh and R. H. Christian, Phys. Rev. 97, 1544 (1955).

11. A. Zalkin, "The Thermal Expansion of LiH," University of California Radiation Laboratory report UCRL-4239 (November 1953).
12. :I. Laquer, "Low-Temperature Thermal Expansion of Various Materials, "Los Alamos Scientific Laboratory report LA-1505 (December 1952).

is. H. Laquer and E. Head, private communication to Tannenbaum (see Ref. 14).

14. I. R. Tannenbaum and F. H. Ellinger, "The Thermal Expansion of Lithium Hydride in the Temperature Range $0-500^{\circ} \mathrm{C}$, "Los Alamos Scientific Laboiatory report LAMS-1650 (July 1954).

15. A. Goldsmiih, T. E. Waterman, and H. J. Hirschhorn, "Thermophysical Properties of Solid Materials," Vol. IV, Wright Air Development Division report WADC-TR-58-476 (November 1960).

16. JANAF $\mathrm{T}$ hermochemical Tables

(D. R. Stull, Project Director), The Thermal Research Laboratory, Dow Chemical Company, Midiand, Michigan (September 1967).

17. D, R. Stephens and E. M. Lilley, J. Appl. Phys. 39, 177 (19i8).

18. D. P. Schumaches, Phys. Rev. 126, 1679 (1962).

19. F. F. Voronov, V. A. Goncharova, O. V. Stal'gorova, and T. A. Agapova, Soviet Physics - Solid State 8,1313 (1966)

20. D. T. Griggs, W. G. McMillan,

E. D. Michael, and C. P. Nash, Phys. Rev. 109, 1858 (1958).

21. R. Weil and A. W. Lawson, J. Chem. Phys. 37, 2730 (1962).

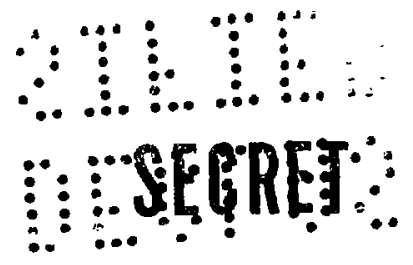



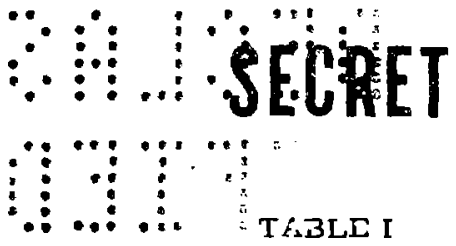

CRYSTAL DENSITIES OF $\mathrm{Li}^{6} \mathrm{H}, \mathrm{Li}^{6} \mathrm{D}, \mathrm{Li}^{\mathrm{n}} \mathrm{H}$, AND $\mathrm{Li}^{\mathrm{n}} \mathrm{D}$

Corrected for Assumed 2 wt $\%$ Hydroxide or

Pire Isolopes

\begin{tabular}{|c|c|}
\hline Material & $\begin{array}{l}\text { Density } \\
\left(\mathrm{g} / \mathrm{cm}^{3}\right) \\
\end{array}$ \\
\hline $\mathrm{Li}^{6} \mathbf{H}$ & 0.6842 \\
\hline $\mathrm{Li}^{6} \mathrm{D}$ & .7905 \\
\hline $\mathrm{Li}^{7} \mathrm{H}$ & .7830 \\
\hline$L i^{7} D$ & .8900 \\
\hline
\end{tabular}

Isotopic Purity for this Study

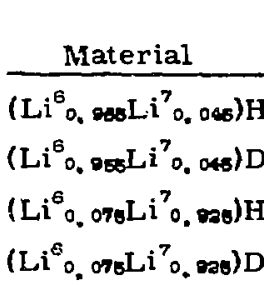
Deuteroxide

Density

$\left(\mathrm{g} / \mathrm{cm}^{3}\right)$

0.696

.802

.78 .3

.890

TABLE II

SOUND VELOCITIES AND ELASTIC MODULI OF Li ${ }^{6} \mathrm{H}, \mathrm{Li}^{6} \mathrm{D}, \mathrm{Li}^{\mathrm{n}} \mathrm{H}$, AND $\mathrm{Li}^{\mathrm{n}} \mathrm{D}$

\section{Density}

Material $\left(\mathrm{g} / \mathrm{cm}^{3}\right)$

$\mathrm{Li}{ }^{6} \mathrm{H}$

0.698

$L i^{9} \mathbf{D}$

.799

$\mathrm{Li}^{\mathrm{n}} \mathrm{H} \quad .782$

$L \mathrm{i}^{\mathrm{n} D} \quad .894$

$\mathrm{Li}^{8} \mathrm{H} \quad .666$

$\mathrm{Li}^{6} \mathrm{D} \quad .764$

$\mathrm{Li}^{\mathrm{A}} \mathrm{H} \quad .743$

$\mathrm{Li}^{\mathrm{n} D} \quad .840$
Sound Velocities $(\mathrm{km} / \mathrm{sec})$

\begin{tabular}{|c|c|c|}
\hline$V_{L}$ & $\mathrm{~V}_{3}$ & $C_{b}$ \\
\hline 10.67 & 7.18 & 6.72 \\
\hline 10.10 & 6.80 & 6.35 \\
\hline 10.05 & 6.75 & 6.34 \\
\hline 9.56 & 6,43 & 6.0 \\
\hline
\end{tabular}

10.42

6.86

ว. 72

6.53

9.84

6.61

9. 36

6.31
Elastic Moduli (kbar)

\begin{tabular}{lllll}
\hline Bs & $\frac{\mu}{Y}$ & $\frac{Y}{781}$ & $\frac{B_{L}}{794}$ & $\frac{\sigma}{0.086}$ \\
314 & 359 & 781 & & \\
322 & 369 & 802 & 815 & .085 \\
314 & 356 & 776 & 789 & .089 \\
324 & 369 & 803 & 817 & .087
\end{tabular}

TABLE III

ELASTIC CONSTANTS OF $\mathrm{Li}^{\mathrm{n}} \mathrm{H}, \mathrm{Li}^{7} \mathrm{H}$, AND $\mathrm{Li}^{7} \mathrm{D}$

$$
\mathrm{V}_{15}[110] \quad \mathrm{V}_{25}[110]
$$

$\xi$ along $\xi$ along

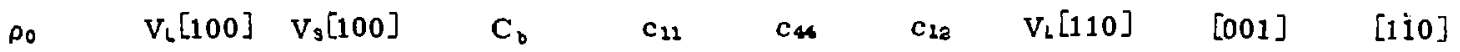

Mat $\left(\mathrm{g} / \mathrm{cm}^{3}\right) \underline{(\mathrm{km} / \mathrm{sec})} \underline{(\mathrm{km} / \mathrm{sec})} \underline{(\mathrm{km} / \mathrm{sec})} \underline{(\mathrm{kbar})} \underline{(\mathrm{kbar})}(\mathrm{kbar}) \quad(\mathrm{km} / \mathrm{sec}) \quad(\mathrm{km} / \mathrm{sec})(\mathrm{km} / \mathrm{sec})$

$\mathrm{Li}^{\mathrm{n}} \mathrm{H} \quad 0.776$

9.06

7,40

6.34

636

424

150

10.55

7, 62

5.77

10.26 *

7. 40 *

$5.60^{*}$

$\mathrm{Li}^{7} \mathrm{H}$

9.02

7. 39

6. 34

637

$428 \quad 154$

10.50

7. 70

5.80

$10.25^{\text {** }}$

7. $39^{\text {* }}$

$5.56^{*}$

$\mathrm{Li}^{7} \mathrm{D} \quad .890$

$8.38 \quad 6.81$

6.02

626

419

$9.58^{*}$

$6.81^{*}$

$5.05^{*}$

"Calculated

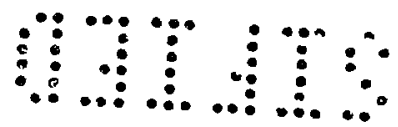


TABLE IV

HUGONIOT DATA FOR $\mathrm{Li}^{6} \mathrm{D}\left(\bar{\rho}_{0}=0.798 \mathrm{~g} / \mathrm{cm}^{3}\right)$
TABLE VI

HUGONIOT DATA FOR $\mathrm{Li}^{6} \mathrm{D}\left(\bar{\rho}_{0}=0.738 \mathrm{~g} / \mathrm{cm}^{3}\right)$

\begin{tabular}{|c|c|c|c|c|c|c|c|c|c|c|c|}
\hline$\stackrel{\rho_{0}}{\left(g / \mathrm{cm}^{3}\right)}$ & $\begin{array}{c}\mathrm{U}_{\mathrm{*}} \\
(\mathrm{km} / \mathrm{sec})\end{array}$ & $\begin{array}{c}U_{p} \\
(\mathrm{~km} / \mathrm{sec})\end{array}$ & $\begin{array}{c}P \\
\text { (Mbar) }\end{array}$ & $\begin{array}{c}\rho \\
\left(\mathrm{g} / \mathrm{cm}^{\mathrm{s}}\right)\end{array}$ & $\begin{array}{c}U_{3} \text { atd } \\
(\mathrm{km} / \mathrm{sec})\end{array}$ & $\begin{array}{c}\rho_{0} \\
\left(\mathrm{~g} / \mathrm{cm}^{3}\right)\end{array}$ & $\begin{array}{c}\mathrm{U}_{2} \\
(\mathrm{~km} / \mathrm{sec})\end{array}$ & $\begin{array}{c}\mathrm{U} \\
(\mathrm{km} / \mathrm{sec})\end{array}$ & $\begin{array}{c}\mathbf{P} \\
\text { (Mrbar) }\end{array}$ & $\frac{p}{\left(\mathrm{~g} / \mathrm{cm}^{3}\right)}$ & $\begin{array}{l}U_{3} \text { atd } \\
(\mathrm{km} / \mathrm{sec})\end{array}$ \\
\hline 0.792 & 7.39 & 0.69 & 0.040 & 0.874 & 5.96 & 0.736 & 5. 35 & 0.75 & 0.030 & 0.957 & 5.96 \\
\hline .805 & 7.56 & .91 & .055 & .915 & 6.17 & .737 & 5.96 & $=98$ & .043 & .882 & 6.17 \\
\hline .798 & 7.98 & 1.31 & .083 & .955 & 6.53 & .733 & 6.70 & 1.39 & .068 & .925 & B. 53 \\
\hline .799 & $8.4 B$ & 1.71 & .116 & 1.001 & 6.91 & .731 & 7.38 & 1.80 & .097 & .987 & 8.81 \\
\hline .798 & 9.15 & 2.43 & .177 & 1.086 & 7.59 & $.73 \theta$ & 8.41 & 2,52 & .157 & 1.055 & 7.59 \\
\hline .800 & 9.44 & 2.66 & .201 & 1.113 & 7.81 & .733 & 8.76 & 2,76 & .177 & 1.071 & 7.81 \\
\hline .798 & 9.67 & 2.80 & .216 & 1.122 & 7.95 & .737 & B. 98 & 2.90 & .192 & 1.088 & 7.85 \\
\hline .799 & 10.00 & 3.12 & .249 & 1.162 & 8.26 & .741 & 9,34 & 3.23 & .224 & 1.133 & 8.26 \\
\hline .799 & 10.31 & 3.28 & .268 & 1,177 & 8.41 & .735 & 9.47 & 3,41 & .237 & $1.14 \theta$ & 6.41 \\
\hline .798 & 10,37 & 3.47 & .287 & 1,199 & 8.59 & .738 & 9.82 & 3,58 & .259 & 1,162 & 8.59 \\
\hline $.79 B$ & 10.63 & 3.79 & .321 & 1.239 & 8. 89 & .739 & 10.21 & 3.89 & .294 & 1,195 & 8.89 \\
\hline .798 & 10,79 & 3,79 & .327 & 1.231 & 8.91 & .741 & 10.30 & 3,91 & .298 & 1.184 & 8.91 \\
\hline .797 & 11.04 & 4.06 & .357 & 1.260 & 9.16 & .738 & 10.46 & 4.15 & .320 & 1.223 & 9.12 \\
\hline .798 & 11.22 & 4,21 & .377 & 1.277 & 9.31 & .740 & 10.55 & 4,18 & . 32.6 & 1.226 & 9.16 \\
\hline .798 & 11.24 & 4.39 & .394 & 1,309 & 9.46 & .739 & 10.84 & 4.33 & .347 & 1.230 & 9.31 \\
\hline .798 & 11,18 & 4.40 & .393 & 1,316 & 9.47 & $.7 / 2$ & 11.09 & 4,48 & .969 & 2.245 & 8.46 \\
\hline . 797 & 11.73 & 4.61 & .432 & 1.314 & 9.70 & .740 & 11.08 & 4.50 & .368 & 1.247 & 9.47 \\
\hline .794 & 11.84 & 4.70 & .442 & 1.918 & 8. 78 & .744 & 11.34 & 4.73 & .398 & 1.276 & 9.70 \\
\hline \multirow[t]{2}{*}{. 797} & 11.72 & 4.71 & .440 & 1.394 & 9,78 & .738 & 11.56 & 4.82 & .411 & $\$, 265$ & 8.78 \\
\hline & & & & & & .736 & 11.45 & 4. 83 & .407 & 1.274 & 9,78 \\
\hline
\end{tabular}

TABLE V

HUGONIOT DATA FOR $\mathrm{Li}^{6} \mathrm{D}\left(\bar{p}_{0}=0.764 \mathrm{~g} / \mathrm{cm}^{3}\right)$

$\begin{array}{cc}0 & U_{3} \text {.1 } \\ \left(\mathrm{g} / \mathrm{cm}^{3}\right) & (\mathrm{km} / \mathrm{sec}) \\ 0.866 & 5.94 \\ .868 & 5.95 \\ .899 & 6.16 \\ .903 & 6.20 \\ .938 & 6.54 \\ .943 & 6.55 \\ .950 & 6.57 \\ .943 & 6.56 \\ .951 & 6.56 \\ .955 & 6.56 \\ .979 & 6.86 \\ .969 & 6.86 \\ .990 & 6.90 \\ .991 & 6.93 \\ .996 & 6.94 \\ 1.058 & 7.49 \\ 1.052 & 7.51 \\ 1.089 & 7.71 \\ 1.085 & 7.71 \\ 1.140 & 8.91 \\ 1.143 & 8.22 \\ 1.124 & 8.23 \\ 1.191 & 8.71 \\ 1.188 & 8.75 \\ 1.184 & 8.75 \\ 1.200 & 8.79 \\ 1.215 & 6.95 \\ 1.293 & 9.54 \\ 1.299 & 9.82 \\ 1.319 & 9.86 \\ 1.297 & 9.88 \\ 1.337 & 9.90 \\ 1.367 & 10.28 \\ 1.366 & 10.36\end{array}$

$1.366 \quad 10.3 \epsilon$
TABLE VII

HUGONIOT DATA FOR Li ${ }^{6} \mathrm{D}\left(\bar{\rho}_{0}=0.665 \mathrm{~g} / \mathrm{cm}^{3}\right)$

\begin{tabular}{|c|c|c|c|c|c|}
\hline $\begin{array}{c}\text { p. } \\
\left(\mathrm{g} i \mathrm{~cm} \mathrm{~m}^{3}\right)\end{array}$ & $\begin{array}{c}\mathrm{U}_{3} \\
(\mathrm{~km} / \mathrm{sec})\end{array}$ & $\begin{array}{c}\text { U, } \\
(\mathrm{km} / \mathrm{sec})\end{array}$ & $\begin{array}{c}\mathbf{P} \\
\text { (Mbar) }\end{array}$ & $\left(\mathrm{g} / \mathrm{cm}^{3}\right)$ & $\begin{array}{c}U_{2 m a} \\
(\mathrm{~km} / \mathrm{sec})\end{array}$ \\
\hline 0.668 & 3.66 & 0.81 & 0.020 & 0.858 & 5.96 \\
\hline .672 & 4.57 & 1.05 & .032 & .872 & 6.17 \\
\hline .660 & 5.49 & 1.47 & .053 & .902 & 6.53 \\
\hline .668 & 6.36 & 1.89 & .080 & .951 & 6.91 \\
\hline .670 & 7.71 & 2.63 & .136 & 1.016 & 7.58 \\
\hline .669 & 8.07 & 2.87 & .155 & 1.038 & 7.81 \\
\hline .577 & B. 34 & 3.00 & .170 & 1.058 & 7.95 \\
\hline .667 & 8.64 & 3.37 & .194 & 1.099 & 8.26 \\
\hline .664 & 8.98 & 3.53 & .210 & 1.093 & 8.41 \\
\hline . 632 & 9.23 & 3.72 &, 227 & 1.108 & 8.59 \\
\hline .675 & 9.86 & 4.01 & .267 & 1.137 & 8.89 \\
\hline .656 & 9.90 & 4.05 & .293 & 1. 110 & 8.91 \\
\hline .666 & 9.95 & 4.29 & .284 & 1.170 & 9.12 \\
\hline .676 & 10.23 & 4.30 & .297 & 1. 166 & 9.16 \\
\hline .676 & 10.51 & 4.45 & .316 & 1. 171 & 9.31 \\
\hline .664 & 10.59 & 4.65 & .327 & 1.184 & 9.47 \\
\hline .637 & 10.34 & 4.71 & .310 & 1. 169 & 9.46 \\
\hline .638 & 10.75 & 4.96 &.$\$ 40$ & 1.183 & 9.70 \\
\hline .673 & 11.06 & 4.97 & .370 & 1.222 & 9.78 \\
\hline . 665 & 11.09 & 4.98 & .367 & 1.207 & 9.78 \\
\hline
\end{tabular}

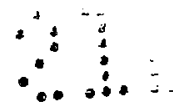




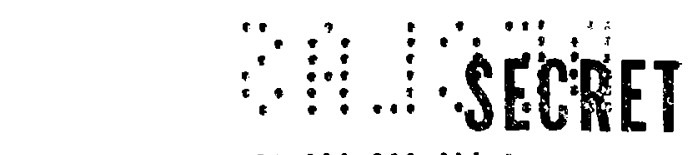

TABLE VIII

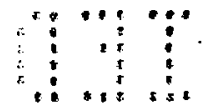

HUGONIOT DATA FOR $\mathrm{Li}^{6} \mathrm{D}\left(\bar{\rho}_{0}=0.579 \mathrm{~g} / \mathrm{cm}^{3}\right)$

TABLE X

HUGONIOT DATA FOR $\mathrm{Li}^{6} \mathrm{D}\left(\bar{\rho}_{0}=0.448 \mathrm{~g} / \mathrm{cm}^{3}\right)$

\begin{tabular}{|c|c|c|c|c|c|c|c|c|c|c|c|}
\hline$\stackrel{p_{0}}{\left(g / \mathrm{cm}^{2}\right)}$ & $\begin{array}{c}U_{k} \\
(\mathrm{~km} / \text { aec })\end{array}$ & $\begin{array}{c}U_{p} \\
(\mathrm{~km} / \mathrm{ses})\end{array}$ & $\begin{array}{c}\mathbf{P} \\
\text { (Mbar). }\end{array}$ & $\begin{array}{c}\rho \\
\left(\mathrm{g} / \mathrm{cms}^{3}\right)\end{array}$ & $\begin{array}{c}U_{3} \ldots \\
(\mathrm{km} / \mathrm{sec})\end{array}$ & $\begin{array}{c}P_{e} \\
\left(g / \mathrm{cm}^{3}\right)\end{array}$ & $\begin{array}{c}\mathrm{ub} \\
(\mathrm{km} / \mathrm{sec})\end{array}$ & $\begin{array}{c}b \\
(\mathrm{~km} / \mathrm{sec})\end{array}$ & $\begin{array}{c}P \\
\text { (Mbar) }\end{array}$ & $\stackrel{p}{\left(\mathrm{~g} / \mathrm{cm}^{3}\right)}$ & $\begin{array}{l}\text { Usal } \\
(\mathrm{km} / \mathrm{sec})\end{array}$ \\
\hline 0. 592 & 2.87 & 0.85 & 0.014 & 0,840 & 5.86 & 0,456 & 2.60 & 1,16 & 0,014 & 0.825 & 6.17 \\
\hline .571 & 3.39 & 1.12 & .022 & .951 & 6.17 & .456 & 3.45 & 1.64 & .128 & .869 & 6.53 \\
\hline .572 & 4.40 & 1.56 & .039 & .885 & 6.53 & .450 & 4.34 & 2.12 & .041 & .879 & 6.91 \\
\hline .587 & 5,34 & 2,00 & .061 & .808 & 6.81 & .457 & 5.80 & 2,93 & .076 & .924 & 7.59 \\
\hline .571 & 6.81 & 2.77 & .108 & .962 & 7.58 & .462 & 6.25 & 3.19 & .092 & .942 & 7.81 \\
\hline .574 & 7.29 & 3.01 & .126 & .977 & 7.81 & .452 & 6.59 & 3.35 & .100 & .920 & $\therefore 85$ \\
\hline .572 & 7.49 & 3,17 & .196 & .981 & 7.93 & .448 & 7.05 & 3. 73 & .118 & .953 & 8,26 \\
\hline .570 & 7.83 & 3.54 & .158 & 1.039 & 8.28 & .425 & 7.48 & 3.93 & .125 & .897 & 8.41 \\
\hline .571 & 8.29 & 3.69 & .175 & 1.029 & 8.41 & .458 & 7.83 & 4.09 & .147 & .959 & 8.59 \\
\hline .575 & 8.59 & 3.88 & .191 & 1.048 & 8.58 & .447 & 8.37 & 4.46 & .167 & .056 & 8.89 \\
\hline .587 & 9.09 & 4.19 & .224 & 1.089 & 8.89 & .441 & 8.42 & 4.48 & .167 & .944 & 8.91 \\
\hline .583 & 0.23 & 4.21 & .227 & 1.072 & 8.91 & .448 & 8.73 & 4.73 & .185 & .974 & 9.12 \\
\hline .579 & 9.35 & 4.47 & .242 & 1.108 & 9.12 & .451 & 9.09 & 4.75 & .194 & .943 & 9.16 \\
\hline .570 & 9.54 & 4.52 & .257 & 1.083 & 9.16 & .444 & 9.39 & 4.92 & .205 & .933 & 8.31 \\
\hline .578 & 9.91 & 4.65 & .266 & 1.088 & 9.31 & .446 & 9.71 & 5.09 & .220 & .937 & 9.46 \\
\hline .586 & 10,23 & 4.79 & .292 & 1.121 & 9.47 & .444 & 9.61 & 5.11 & .218 & .948 & 9.47 \\
\hline .588 & 9.99 & 4.83 & .282 & 1,145 & 8.46 & .450 & 10.04 & 5.36 & .242 & .965 & 9. 70 \\
\hline .594 & 10.48 & 5.06 & . .315 & 1.148 & 9.70 & .434 & 10.20 & 5.49 & .249 & .810 & 9.78 \\
\hline .594 & 10.62 & 5.14 & . 325 & 1,152 & 9.78 & .442 & 10.02 & 5.49 & .243 & .977 & 0.78 \\
\hline .578 & 10.52 & 5.18 & .315 & 1.138 & 9.78 & & & & & & \\
\hline
\end{tabular}

TABLE IX

HUGONIOT DATA FOR Li ${ }^{6} \mathrm{D}\left(\bar{\rho}_{0}=0.514 \mathrm{~g} / \mathrm{cm}^{3}\right)$
TABLE XI

HUGONIOT DATA FOR Li ${ }^{6} \mathrm{H}\left(\bar{\rho}_{0}=0.666 \mathrm{~g} / \mathrm{cm}^{3}\right)$

\begin{tabular}{|c|c|c|c|c|c|c|c|c|c|c|c|}
\hline$\left(g / \mathrm{cm}^{3}\right)$ & $\begin{array}{c}U_{2} \\
(\mathrm{~km} / \mathrm{sec})\end{array}$ & $\begin{array}{c}\mathrm{U}_{r} \\
(\mathrm{~km} / \mathrm{sec})\end{array}$ & $\begin{array}{c}P \\
\text { (Mbar) }\end{array}$ & $\left(g / \mathrm{cm}^{3}\right)$ & $\begin{array}{l}\text { Uame } \\
\text { (km/aec) }\end{array}$ & $\left(\mathrm{g} / \mathrm{cm}^{\mathrm{s}}\right)$ & $\begin{array}{c}U_{1} \\
(\mathrm{~km} / \mathrm{sec})\end{array}$ & $\begin{array}{c}U_{*} \\
(\mathrm{~km} / \mathrm{xec})\end{array}$ & $\begin{array}{c}P \\
\text { (Mber) }\end{array}$ & $\left(\mathrm{g} / \mathrm{cm}^{3}\right)$ & $\begin{array}{c}U_{3} \text { wd } \\
(\mathrm{km} / \mathrm{sec})\end{array}$ \\
\hline 0.522 & 3.01 & 1.14 & 0.018 & 0.840 & 6,17 & 0.669 & 6,42 & 0.72 & 0.031 & 0.753 & 5.94 \\
\hline .526 & 4. 08 & 1.59 & .094 & .801 & 6.53 & .681 & 6. 38 & .73 & .031 & .747 & 5.95 \\
\hline .330 & 4,88 & 2.05 & .053 & .913 & 6.91 & .664 & 6.31 & .79 & .031 & .751 & 5,95 \\
\hline .532 & 6.35 & 2.63 & .096 & .961 & 7.59 & .666 & 6.86 & 1.00 & .045 & .779 & 6.18 \\
\hline .514 & 6.76 & 3.10 & .108 & .950 & 7.81 & .671 & 6.81 & 1.02 & .046 & .769 & 6.20 \\
\hline .527 & 7.18 & 3.24 & .122 & .968 & 7.95 & .661 & 7.49 & 1.42 & .070 & .816 & 6.57 \\
\hline .519 & 7,54 & 3,62 & .142 & $.0: 38$ & 8.26 & .661 & 8.13 & 1.79 & .098 & .847 & 6.90 \\
\hline .521 & 7,88 & 3.78 & .157 & .039 & 8.41 & .662 & 9.02 & 2.43 & .145 & $.90 \prime 7$ & 7.49 \\
\hline .539 & 8,35 & 3.94 & .177 & 1.021 & 8.59 & .660 & 9.91 & 3.18 & .209 & .874 & 6.19 \\
\hline .506 & 9.04 & 1.34 & .198 & .972 & 8.91 & .666 & 10.71 & 3.74 & .266 & 1.023 & 8. 71 \\
\hline .499 & 8.70 & 4.35 & .189 & .899 & 8.89 & .671 & 10.97 & 3.99 & .294 & 1.054 & 8.95 \\
\hline .511 & 9.08 & 4.60 & .213 & 1.035 & 9.12 & .664 & 11,71 & 4.63 & .360 & 1.099 & 9.54 \\
\hline .502 & 9.38 & 4.64 & .218 & .993 & 9.16 & .664 & 12.31 & 4.95 & .404 & 1.110 & 9.86 \\
\hline .506 & 9.72 & 4.78 & .235 & .996 & 9.31 & .664 & 12.41 & 4.99 & .411 & 1.111 & 9.80 \\
\hline .508 & 10,05 & 4.96 & .253 & 1,003 & 9.47 & .664 & 12.73 & 5.40 & .457 & 1.154 & $10.28^{\circ}$ \\
\hline .499 & 9.86 & 4.98 & .245 & 1.009 & 9.46 & .664 & 12.93 & 5.18 & .471 & 1.153 & 10.36 \\
\hline .510 & 10.27 & 5.23 & .274 & 1.038 & 9.70 & & & & & & \\
\hline .497 & 10.51 & 5,33 & .279 & 1.010 & 8.78 & & & & & & \\
\hline .500 & 10.33 & 5.35 & .276 & 1.035 & 8.76 & & & & & & \\
\hline
\end{tabular}

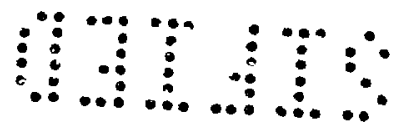


TABLE XII

HUGONIOT DATA FOR Li"H AND Li ${ }^{7} \mathrm{H}$

$$
\left(\tilde{\rho}_{\circ}=0.739 \mathrm{~g} / \mathrm{cm}^{3}\right)
$$

TABLE XIII

HUGONIOT DATA FOR Li $\mathrm{i}^{\mathrm{n}} \mathrm{D}$ AND Li $\mathrm{i}^{\mathrm{T}} \mathrm{D}$

$\left(\bar{p}_{0}=0.840 \mathrm{~g} / \mathrm{cm}^{3}\right)$

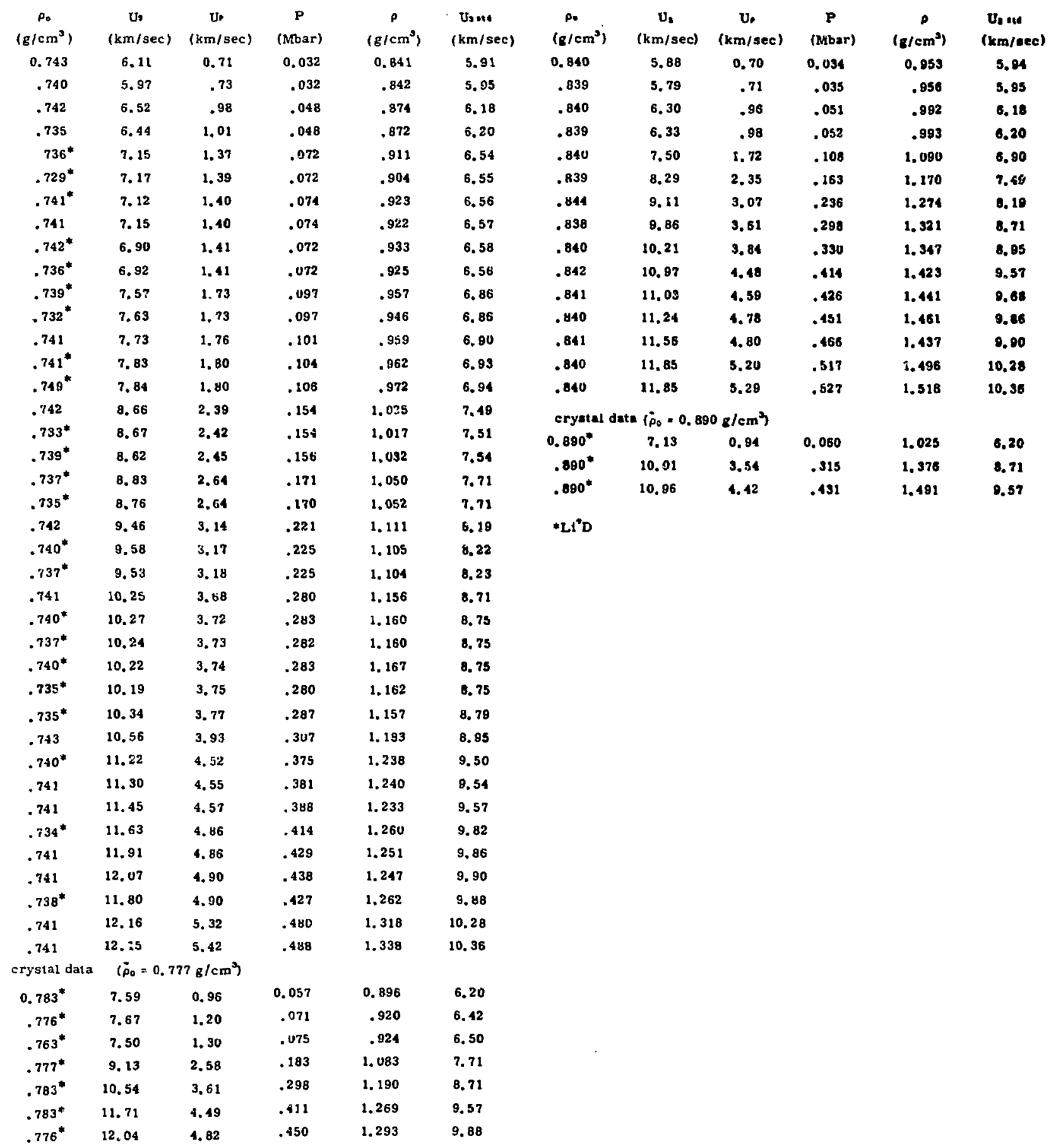

*L1'H

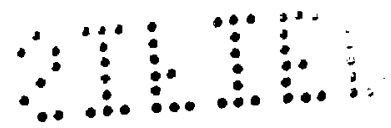




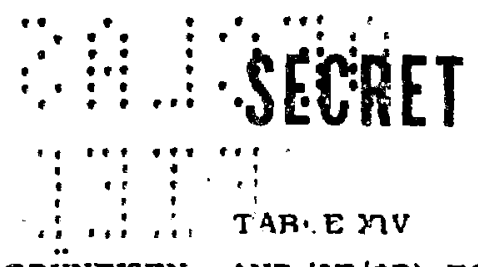

THERMODYNAMIC GRÜNEISEN Y AND (OE/OP), FOR Li $\mathrm{H}, \mathrm{Li} \mathrm{l}^{\mathrm{a}} \mathrm{D}, \mathrm{Li} \mathrm{l}^{\mathrm{a}} \mathrm{H}$, AND LI"D

\begin{tabular}{|c|c|c|c|c|c|c|c|c|}
\hline Mat & $\begin{array}{c}\rho_{0} \\
\left(\mathrm{~g} / \mathrm{cm}^{3}\right)\end{array}$ & $\begin{array}{c}v_{0} \\
\left(\mathrm{~cm}^{3} / \mathrm{g}\right)\end{array}$ & $\begin{array}{c}\beta \\
(/ \mathrm{K}) \\
\end{array}$ & $\begin{array}{c}C_{0} \\
(\mathrm{~cm} / \mathrm{sec}) \\
\end{array}$ & $\begin{array}{c}\mathrm{cr}_{p} \\
\left(\mathrm{cal} / \mathrm{mol}^{\circ} \mathrm{K}\right)\end{array}$ & $\begin{array}{c}c_{p} \\
\left(\operatorname{erg} / g^{\circ} K\right)\end{array}$ & $\gamma$ & $\begin{array}{l}(\partial E / \partial P)_{V} \\
\left(\mathrm{~cm}^{3} / \mathrm{g}\right)\end{array}$ \\
\hline $\mathrm{Li}^{{ }^{\mathbf{B}} \mathrm{H}}$ & 0.689 & 1.451 & $34.9 \times 10^{-6}$ & $6,72 \times 10^{6}$ & 6.682 & 3. $953 \times 10^{7}$ & 0.970 & 1.496 \\
\hline $\operatorname{Li}^{6} \mathbf{D}$ & .795 & 1.258 & 95.1 & 6.35 & 6.682 & 3.461 & 1.108 & 1.135 \\
\hline $\mathrm{Li}^{2} \mathrm{H}$ & .776 & 1.289 & 93.0 & 6.34 & 6.682 & 3.518 & 1.063 & 1.213 \\
\hline$L i^{\circ} \mathrm{D}$ & .883 & 1.133 & 107.7 & 6.02 & 6.682 & 3. 122 & 1.250 & 0.906 \\
\hline
\end{tabular}

TABLE XV

SUMMARY OF CRYSTAL-DENSITY HUGONIOT COEFFICIENTS OF THE EQUATION $\mathrm{U}_{3}=\mathrm{C}_{0}+\mathrm{SU}$, FOR $L 1^{\circ} \mathrm{H}, L 1^{\circ} \mathrm{D}, L i^{n} \mathrm{H}$, AND Li ${ }^{\mathrm{n}} \mathrm{D}$ FOR DATA HAVING $U_{0}>0.9 \mathrm{~km} / \mathrm{sec}$

\begin{tabular}{|c|c|c|c|}
\hline Material & $\begin{array}{c}\rho_{0} \\
\left(\mathrm{~g} / \mathrm{cm}^{3}\right) \\
\end{array}$ & $\begin{array}{c}C_{0} \\
(\mathrm{~km} / \mathrm{sec})\end{array}$ & $\mathbf{s}$ \\
\hline $\mathrm{Li}^{\mathrm{e}} \mathrm{H}$ & 0.696 & 6.740 & 1.189 \\
\hline $\mathrm{Li}^{6} \mathrm{D}$ & .802 & 5.464 & 1.130 \\
\hline $\mathrm{Li}^{\mathrm{a}} \mathrm{H}$ & .783 & 6.426 & 1.167 \\
\hline$L i^{2} \mathrm{D}$ & .890 & 6.138 & 1.151 \\
\hline
\end{tabular}

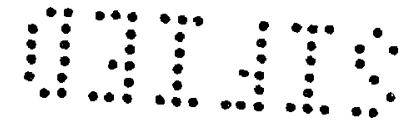




\section{SECRET}

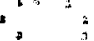

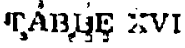 \\ EQUATION OF STATE OF Li ${ }^{6} \mathrm{H}$}

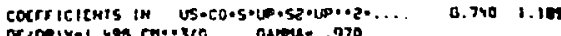

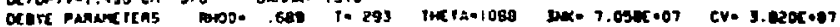

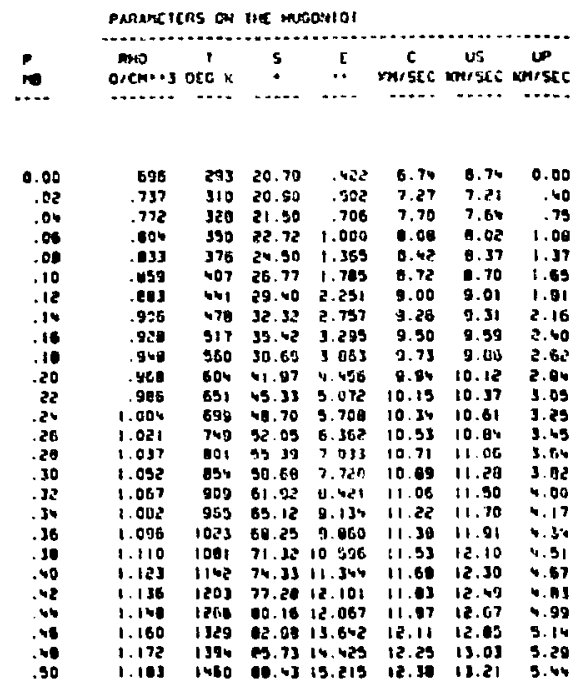

MCLEASE ISCNTROAC IPUD

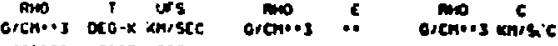

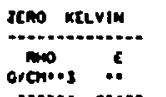

ta isolken

\begin{tabular}{|c|c|c|}
\hline 696 & 293 & 0.00 \\
\hline 1986 & 2914 & .80 \\
\hline $\begin{array}{l}658 \\
693\end{array}$ & $\begin{array}{l}294 \\
307\end{array}$ & $\begin{array}{l}1.41 \\
2.15\end{array}$ \\
\hline 695 & 321 & 2.75 \\
\hline 593 & 330 & 3.30 \\
\hline S98 & 357 & J.eJ \\
\hline 690. & 379 & 0.33 \\
\hline 6BO & No3 & 6.00 \\
\hline GN5 & जel & 5.26 \\
\hline 6914 & 494 & 5.70 \\
\hline Se2 & 41 & 6.13 \\
\hline 679 & 339 & 6.56 \\
\hline 67 & 337 & 6.94 \\
\hline 674 & 368 & 1. 32 \\
\hline 671 & 393 & 7.70 \\
\hline 650 & 625 & 0.07 \\
\hline 664 & 694 & 0.43 \\
\hline 601 & 684 & 0.79 \\
\hline 657 & 719 & 9.13 \\
\hline 656 & 709 & 9.47 \\
\hline 630 & S79 & g.०1 \\
\hline 606 & 006 & 10.10 \\
\hline 642 & 36 & 10.46 \\
\hline 830 & $\begin{array}{l}208 \\
=015\end{array}$ & 10.79 \\
\hline & & \\
\hline
\end{tabular}

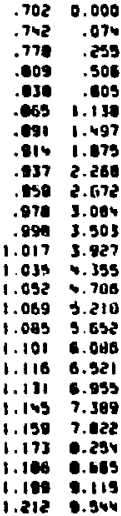

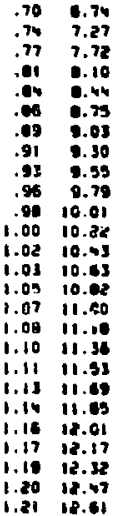

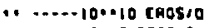

1.

TABLEE XVII

F.QUATION OF STATE OF $\mathrm{Li}^{6} \mathrm{D}$

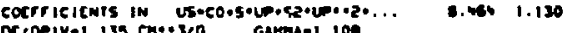

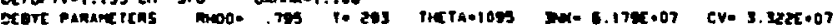

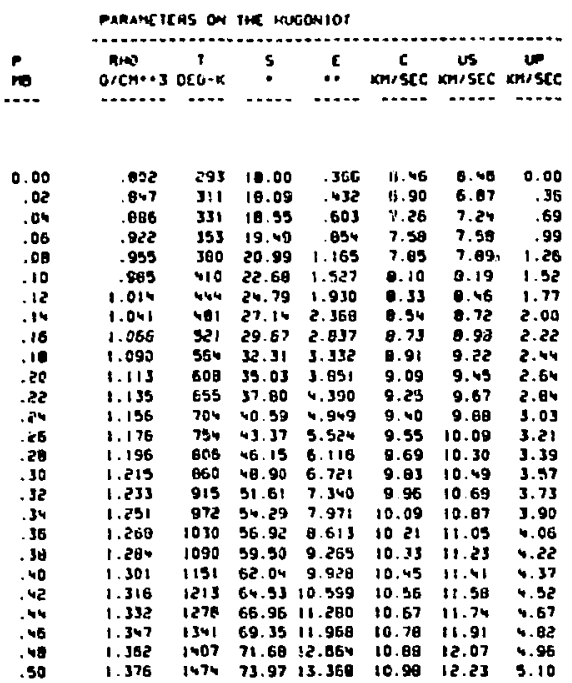

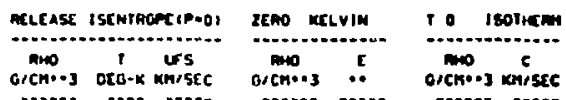

: 

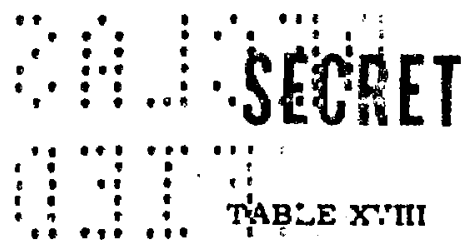

EQUATION OF STATE OF Li"H

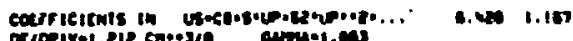

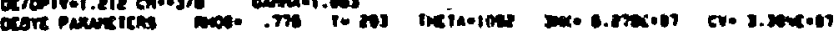

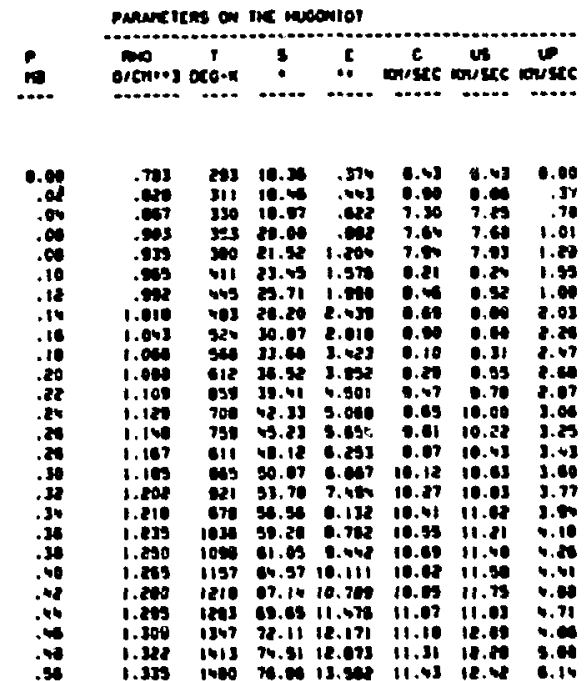

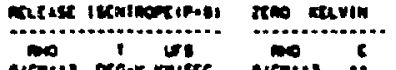

1. Inanem

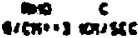



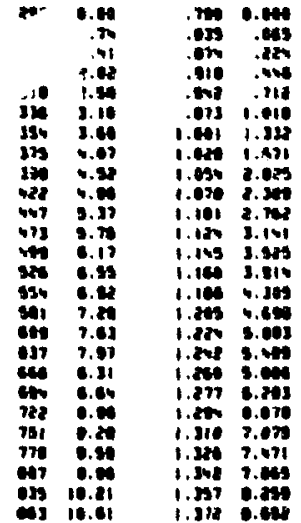

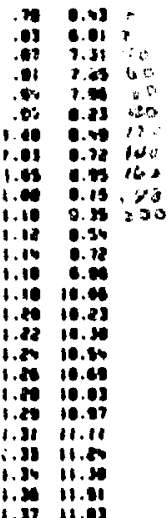

- $-\cdots+10+10$ twosso

TABLE XTX

EQUATION GF STATE OF Li ${ }^{a} D$.

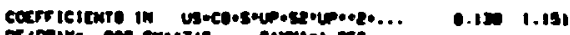

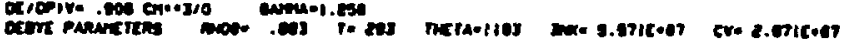

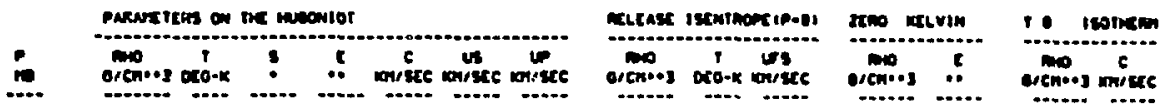

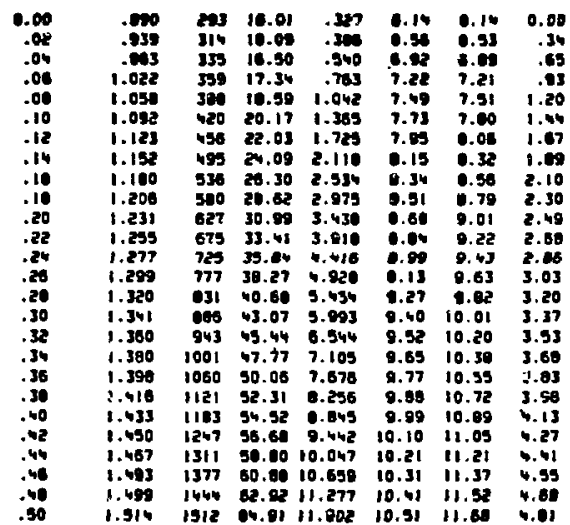

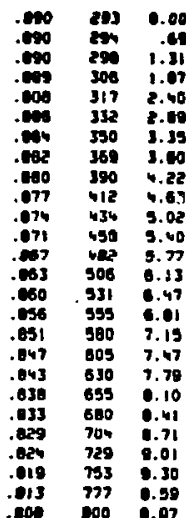

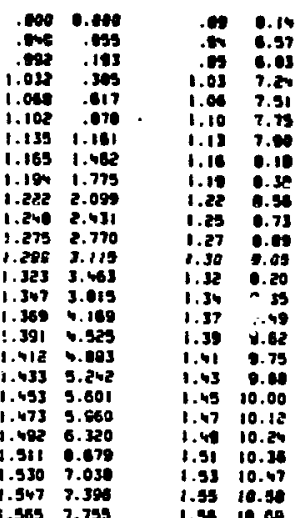

1.-10-100.10 tnosio

- -7--100+0 chosio-dea K

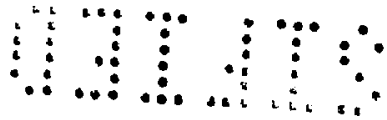




\section{SECREA}

: :

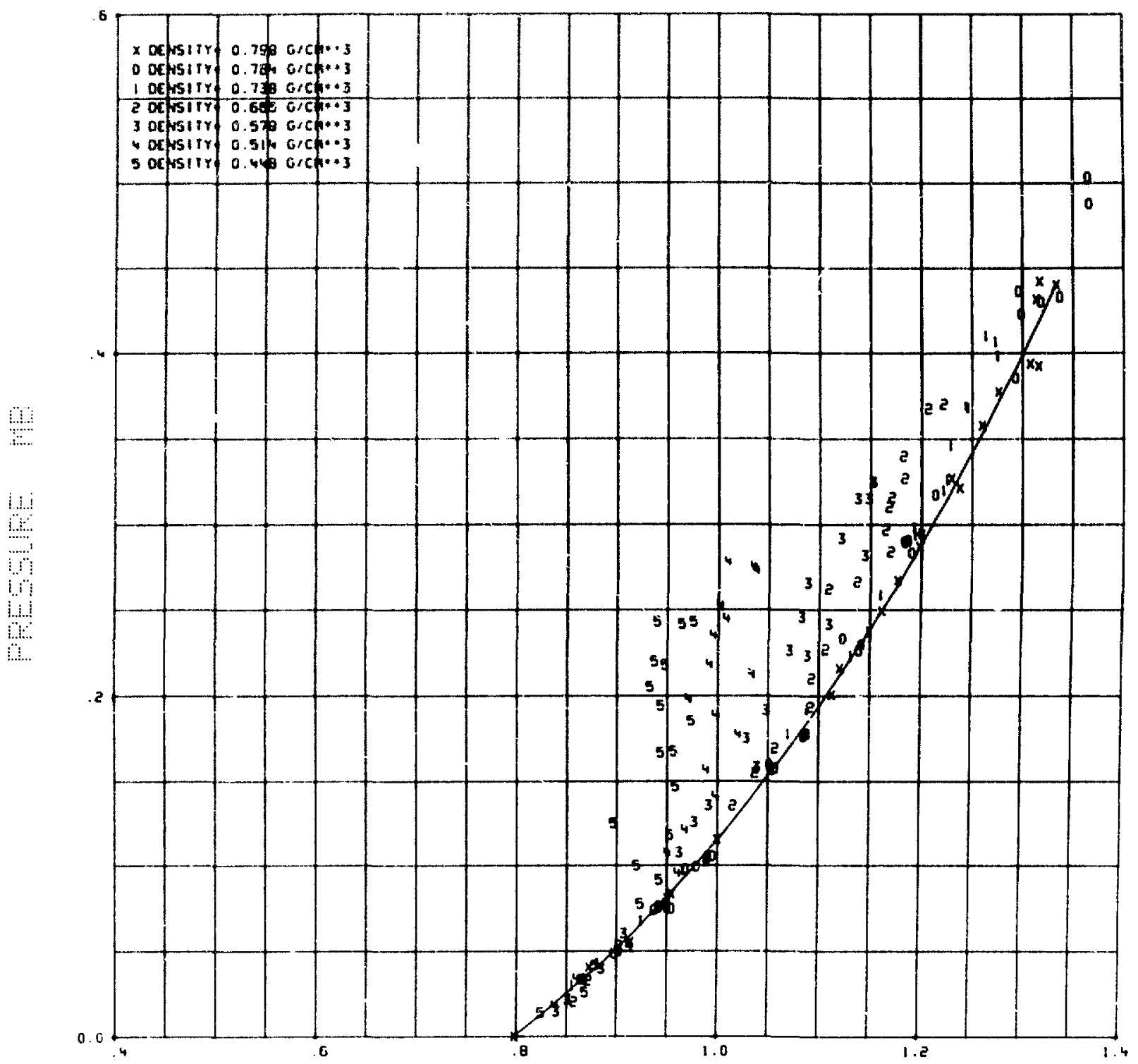

:1:

Fig. 1. Experimental pressure-density Hugoniot data for $\mathrm{Li}^{6} \mathrm{D}$ at seven different porosities. The curve is the fit shown in Fig. 2 . 


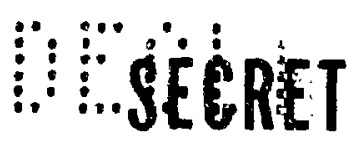

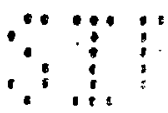

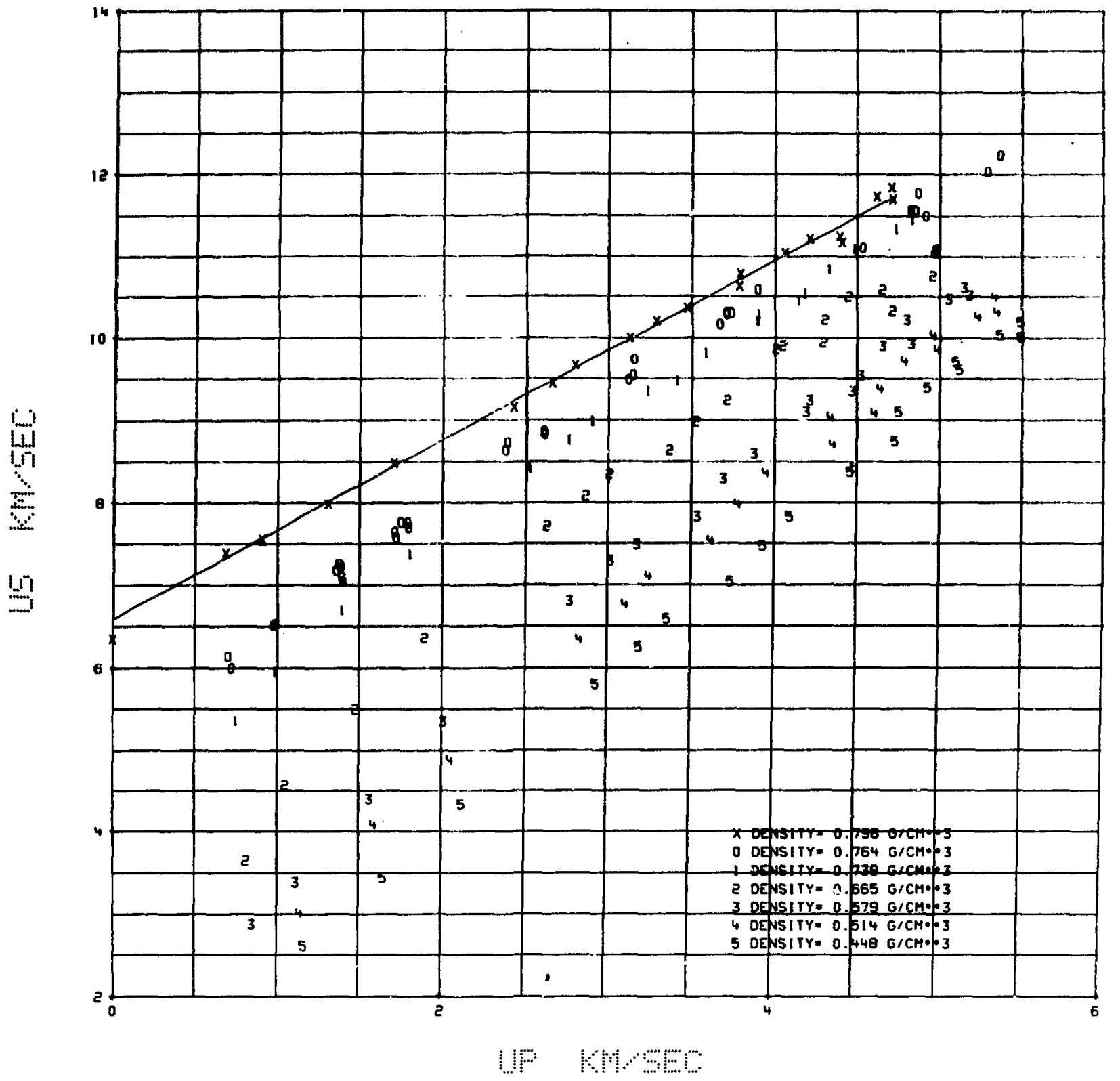

Fig. 2. Experimental shock velocity - particle velocity Hugoniot for $L i^{6} \mathrm{D}$ at seven different porosities. The linear least-squares fit of the data (excluding the bulk sound velocity) of the lowest porosity material is shown. The average density at each porosity is indicated in the legend. The Hugoniots of the porous samples curve downward in a manner predictable by calculations.
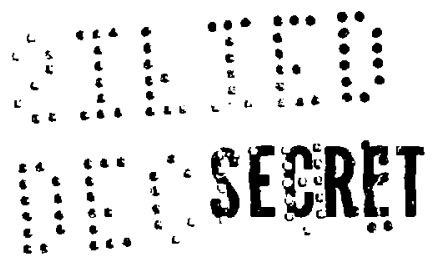


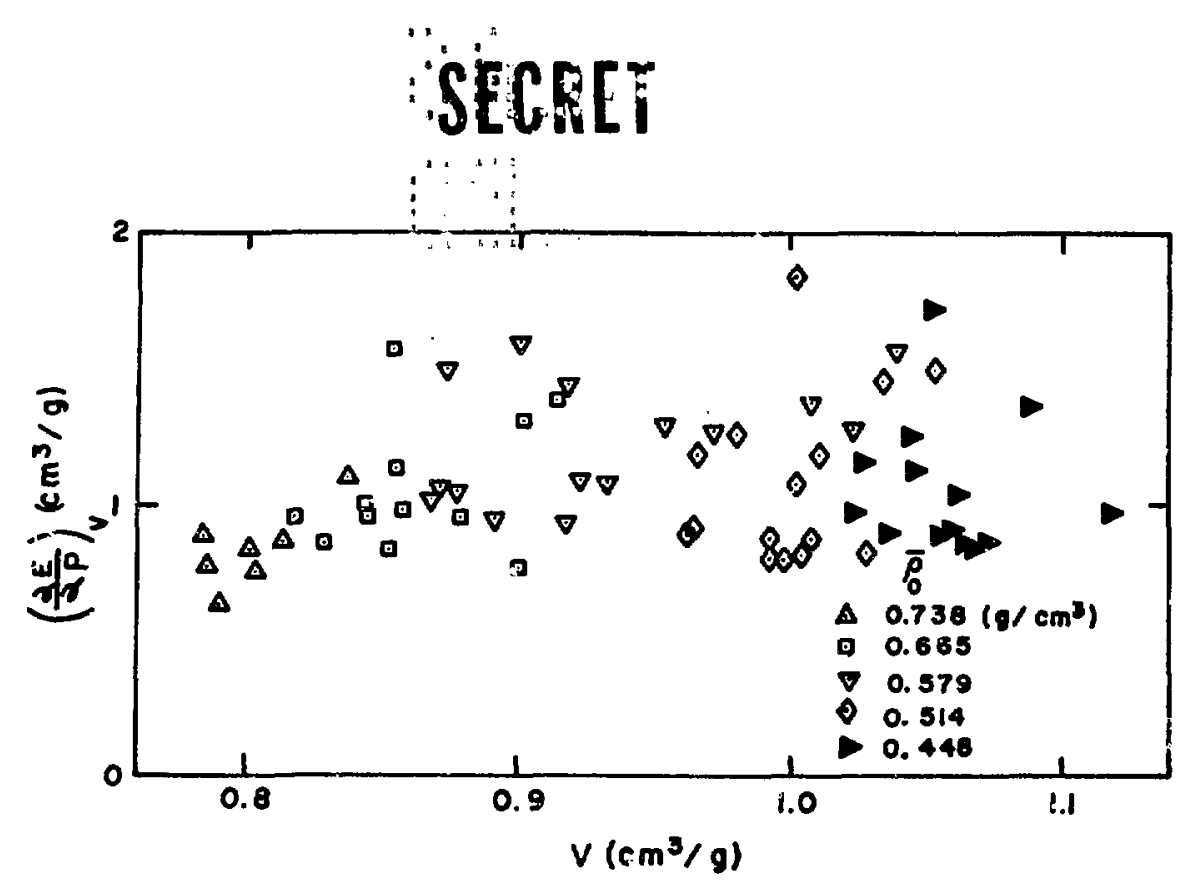

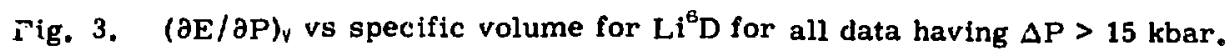

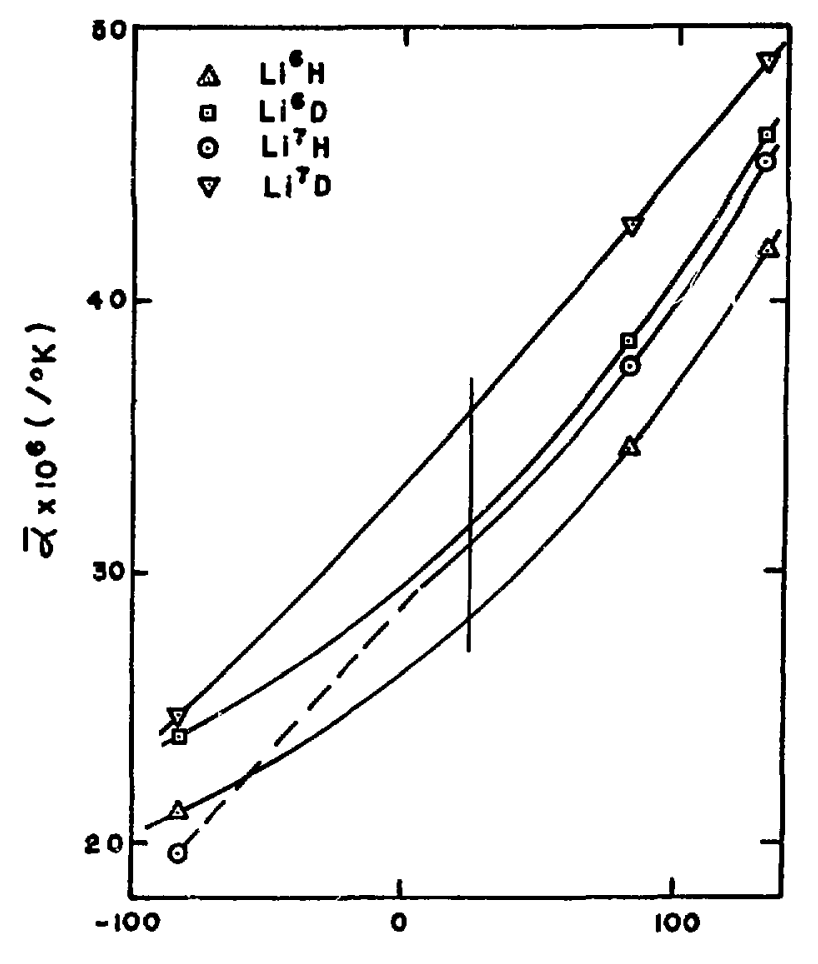

Ave. Temp. $\left({ }^{\circ} \mathrm{C}\right)$

Fig. 4. Average coefficients of linear thermal expansion for $\mathrm{Li}^{6} \mathrm{H}, \mathrm{Li}^{6} \mathrm{D}, \mathrm{Li}^{7} \mathrm{H}$, and $\mathrm{Li} \mathrm{D}$ over the interval $\mathrm{T}$ to $25^{\circ} \mathrm{C}$ using the data of Anderson et al. ${ }^{7}$ The dashed line connects the unexplained low value of $\mathrm{Li}^{7} \mathrm{H}$ at low temperature. The $\bar{\alpha}$ values at $2 \mathrm{C}^{\circ} \mathrm{C}$ are vientical to the instantaneous $\alpha$ vajues $2 i$ that temperature. 


\section{SSEERET}

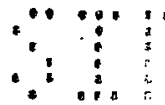

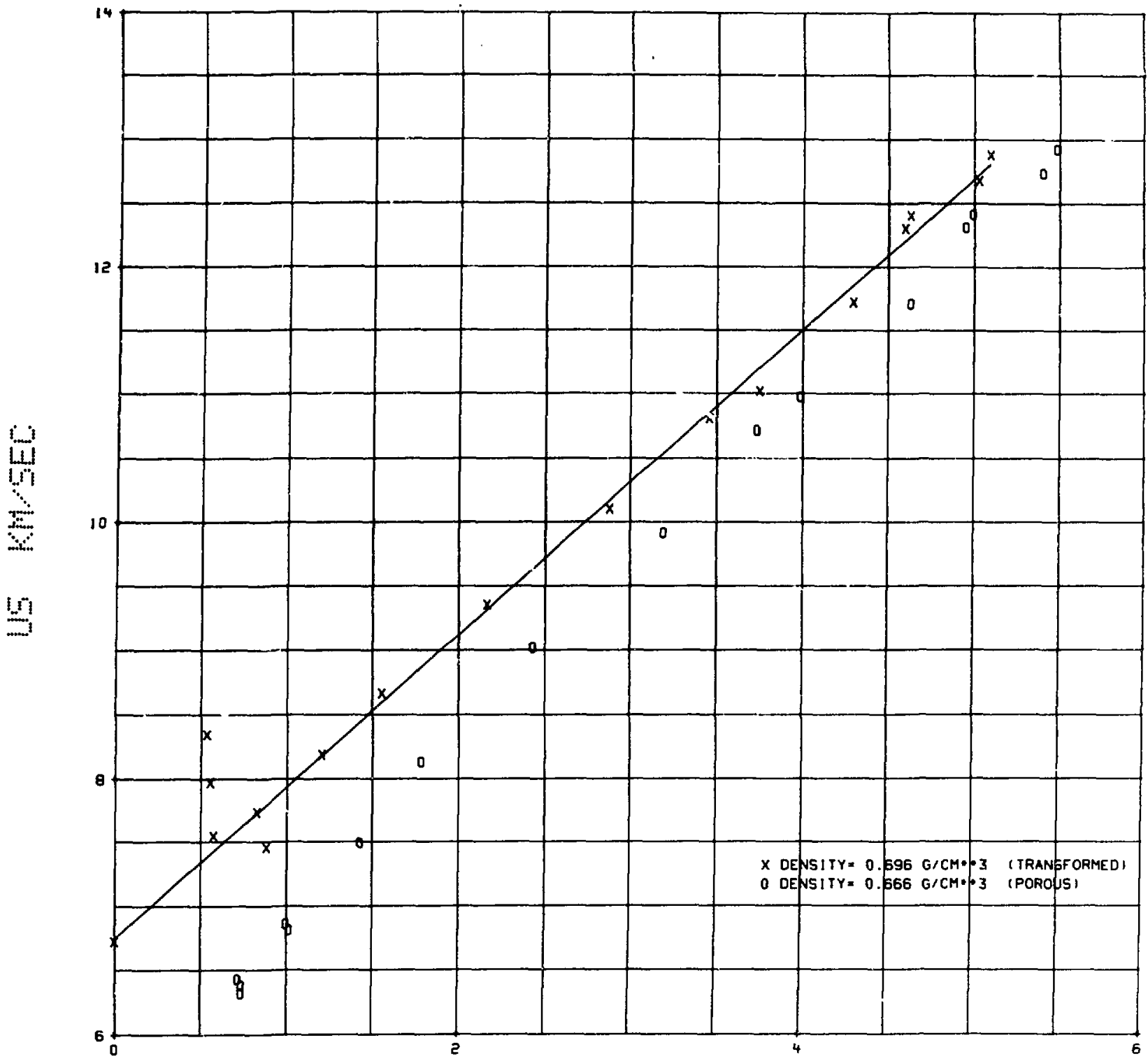

IP.

Fig. 5. Shock velocity - particle velocity Hugoniot data for $\mathrm{Li}^{6} \mathrm{H}$. Experimental porous Hugoniot data and transformed crystal-density Hugoniot points are shown. A linear least-squares fit of the transformed crystal-density points is shown for points haring $U_{p}>0.9 \mathrm{~km} / \mathrm{sec}$.

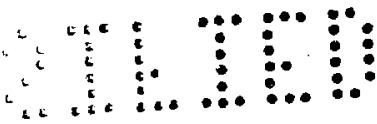




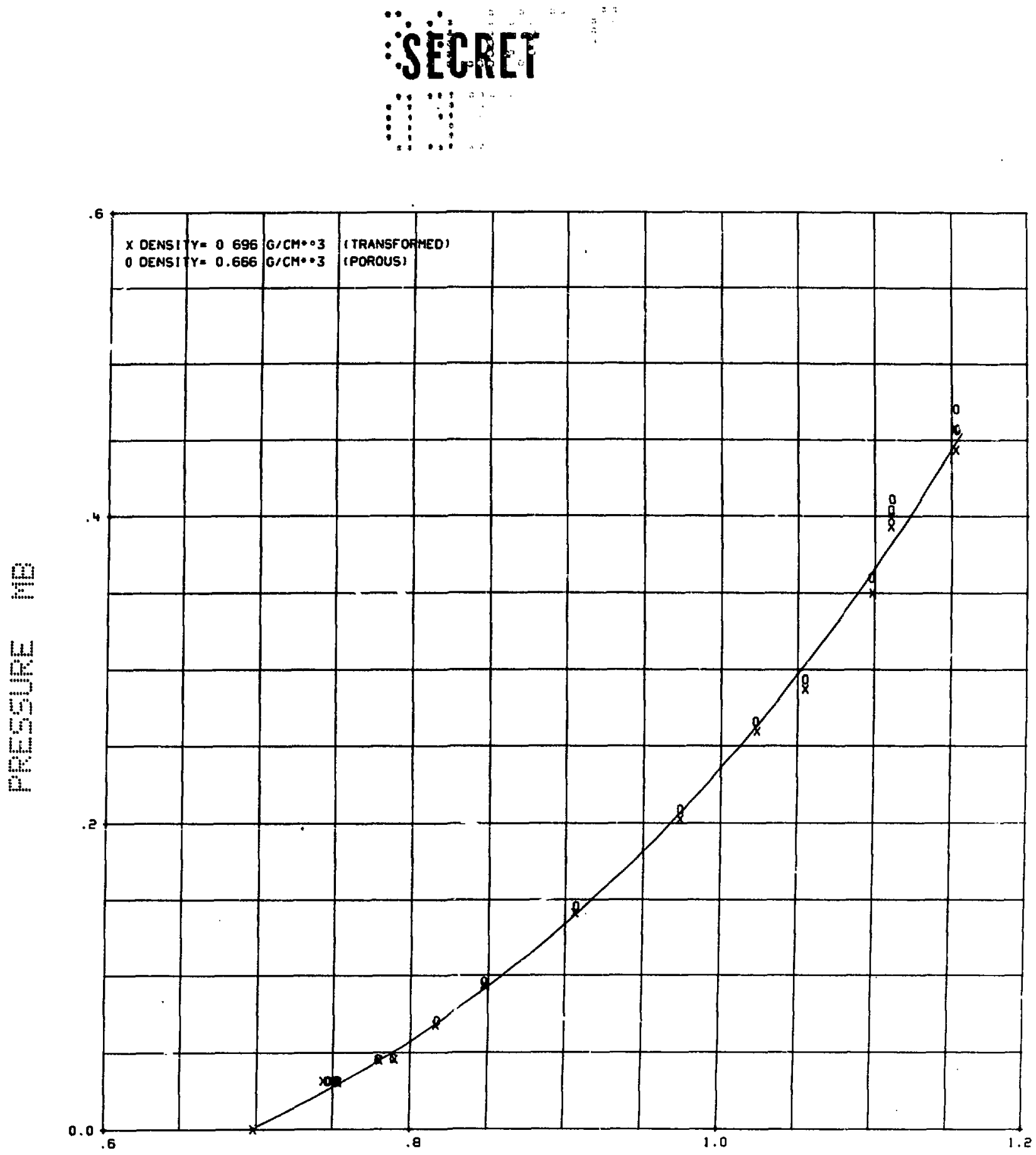

min m)

Fig. 6. Pressure-density Hugoniot data for $\mathrm{L}^{6}{ }^{6} \mathrm{H}$. Experimental porous Hugoniot data and tr ansformed crystal-density Hugoniot points are shown. The curve is the fit shown in Fig. 5.

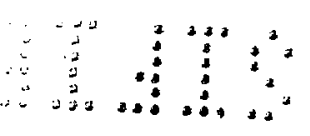




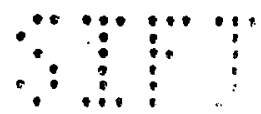

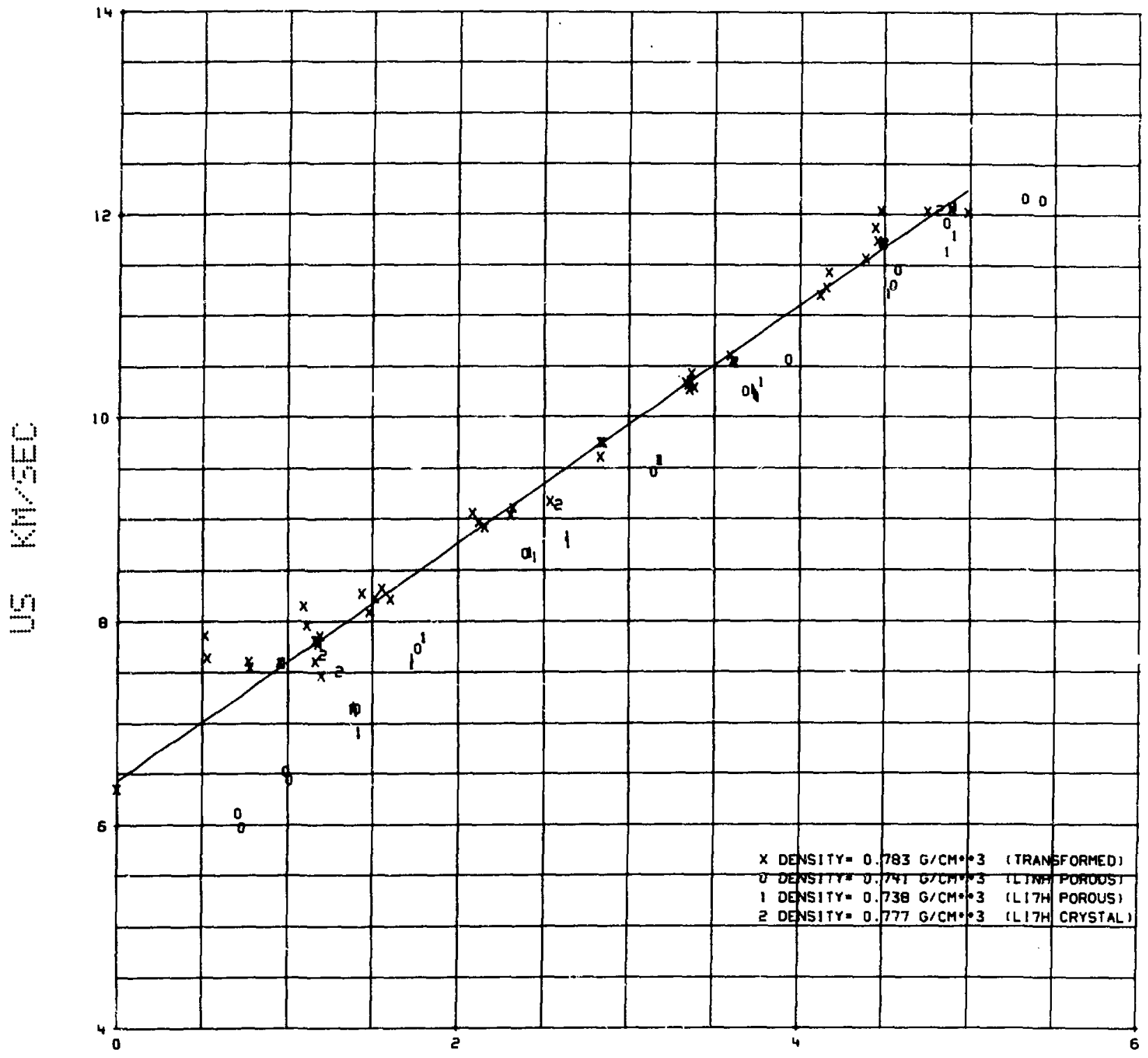

IP $\quad \cdots=$

Fig. 7. Shock velocity - particle velocity Hugoniot data for $L \mathrm{~L}^{\mathrm{n}} \mathrm{H}$ and $\mathrm{Li}{ }^{7} \mathrm{H}$. Experimental porous Hugoniot data for $\mathrm{Li}^{\mathrm{n}} \mathrm{H}$ and $\mathrm{Li}^{7} \mathrm{H}$ are shown along with single-crystal $\mathrm{Li}^{7} \mathrm{H}$ data and transformed crystal-density points of all the data. A linear least-squares fit of the transformed crystaldensity points is shown for points having $U_{p}>0.9 \mathrm{~km} / \mathrm{sec}$. No difference between the $L i^{n} H$ and $\mathrm{Li}^{7} \mathrm{H}$ Hugoniot data is resolved.
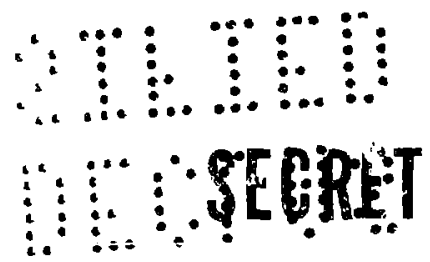


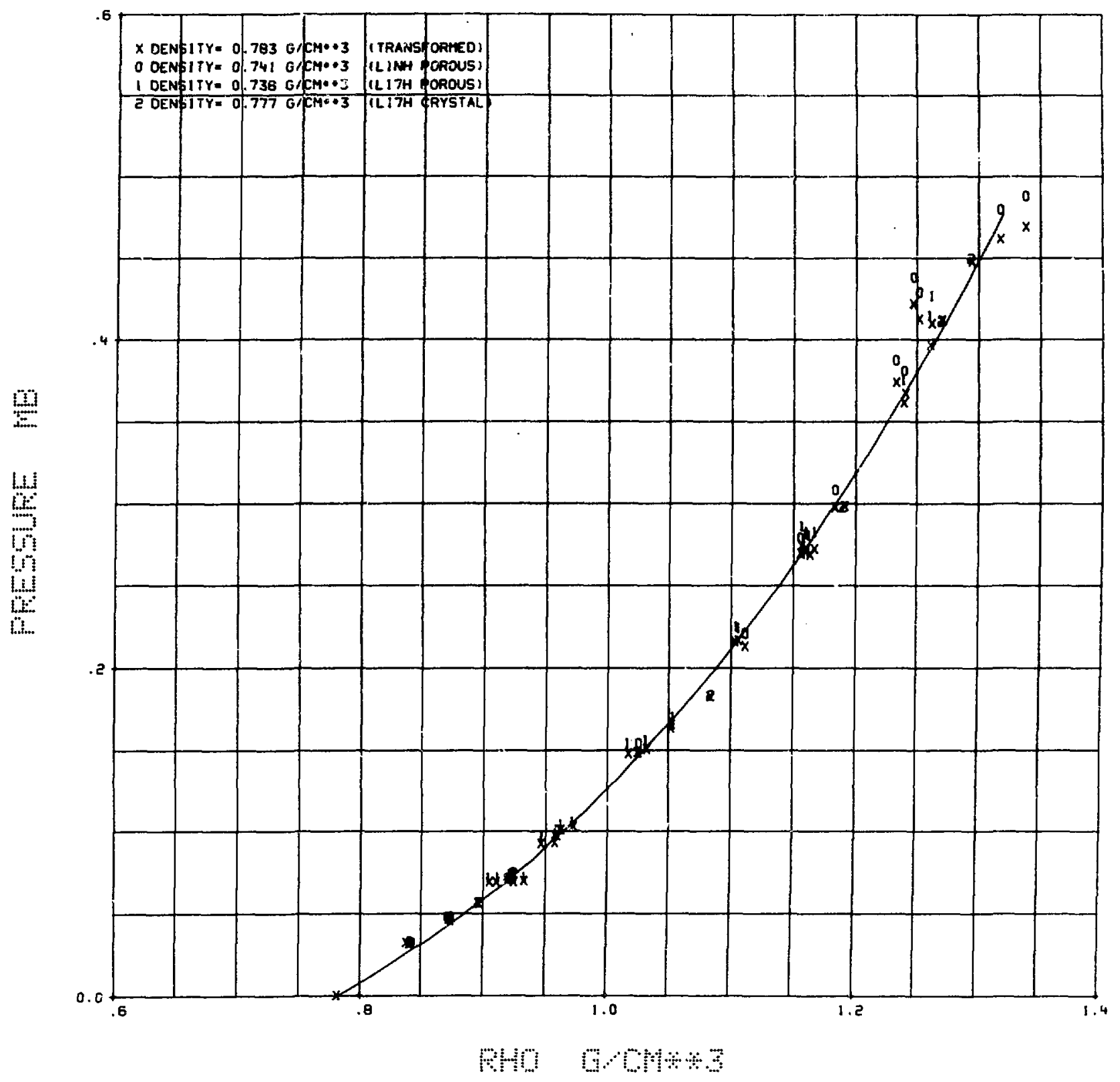

Fig. 8. Pressure-density Hugoniot data for $\mathrm{Li}^{\mathrm{n}} \mathrm{H}$ and $\mathrm{Li}^{7} \mathrm{H}$. Experimental porous Hugoniot data for $\mathrm{Li}^{\mathrm{n}} \mathrm{H}$ and $\mathrm{Li}^{7} \mathrm{H}$ are shown along with experimental single-crystal $\mathrm{Li}^{7} \mathrm{H}$ data and transformed crystaldensity points for all the data. The curve is the fit shown in Fig. 7. 


\section{SéEReT}

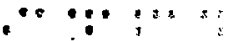

? :

* ex

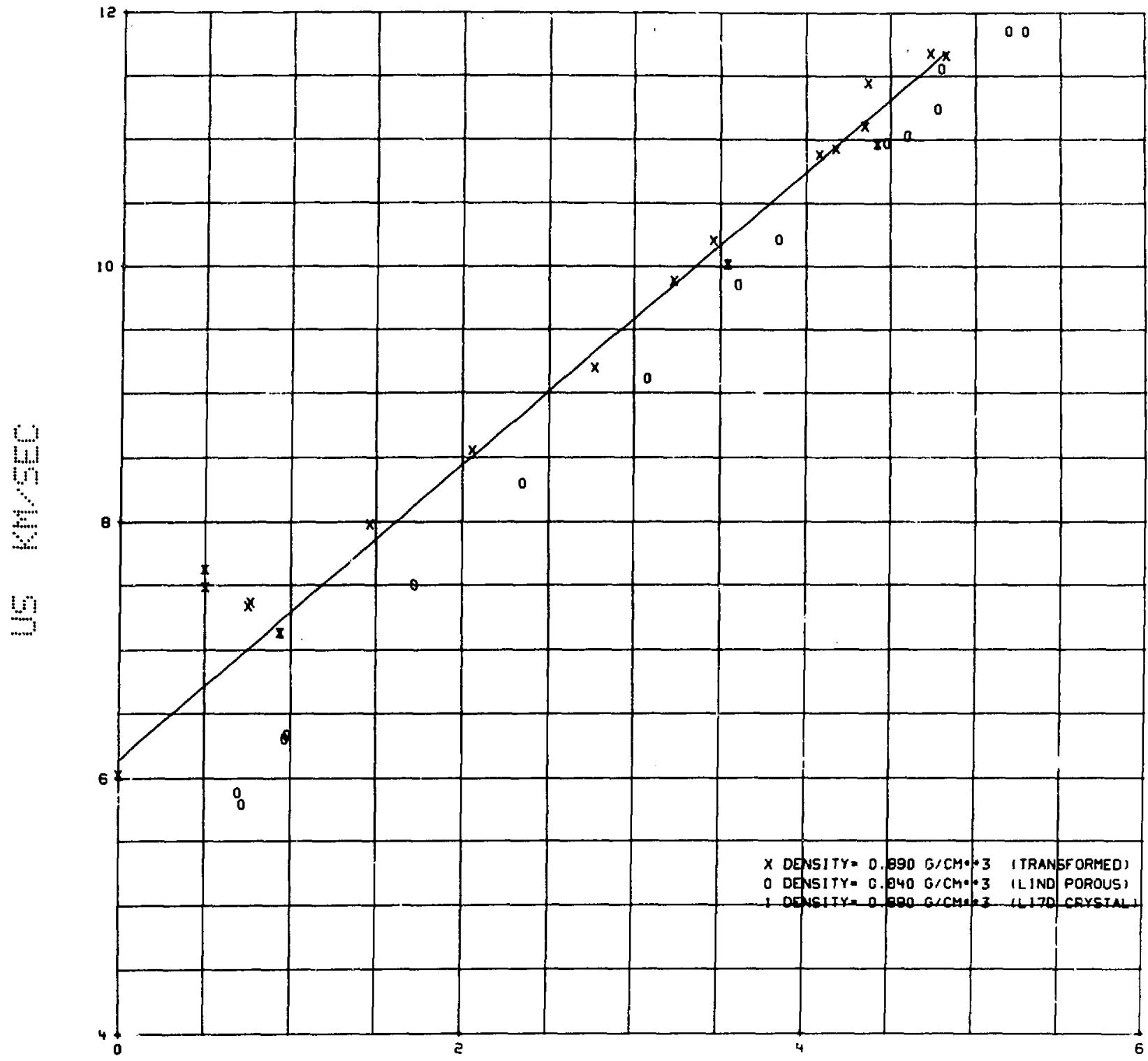

U1:

Fig. 9. Shock velocity - particle velocity Hugoniot data for $\mathrm{Li}^{\mathrm{n}} \mathrm{D}$ and $\mathrm{Li} \mathrm{i}^{7} \mathrm{D}$. Porous Hugoniot data for $\mathrm{L} \mathrm{i}^{\mathrm{D}} \mathrm{D}$ and experimental single-crystal data for $\mathrm{Li}^{7} \mathrm{D}$ are shown along with transformed crystal-density points. A linear least-squares fit of the experimental and transformed crystal-density points is shown $i$ r points having $U_{p}>0.9 \mathrm{~km} / \mathrm{sec}$. The three single-crystal data points lie below the fit. The sason for this difference is not known.

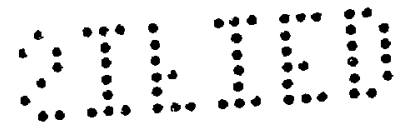


$\because \because \cdots$

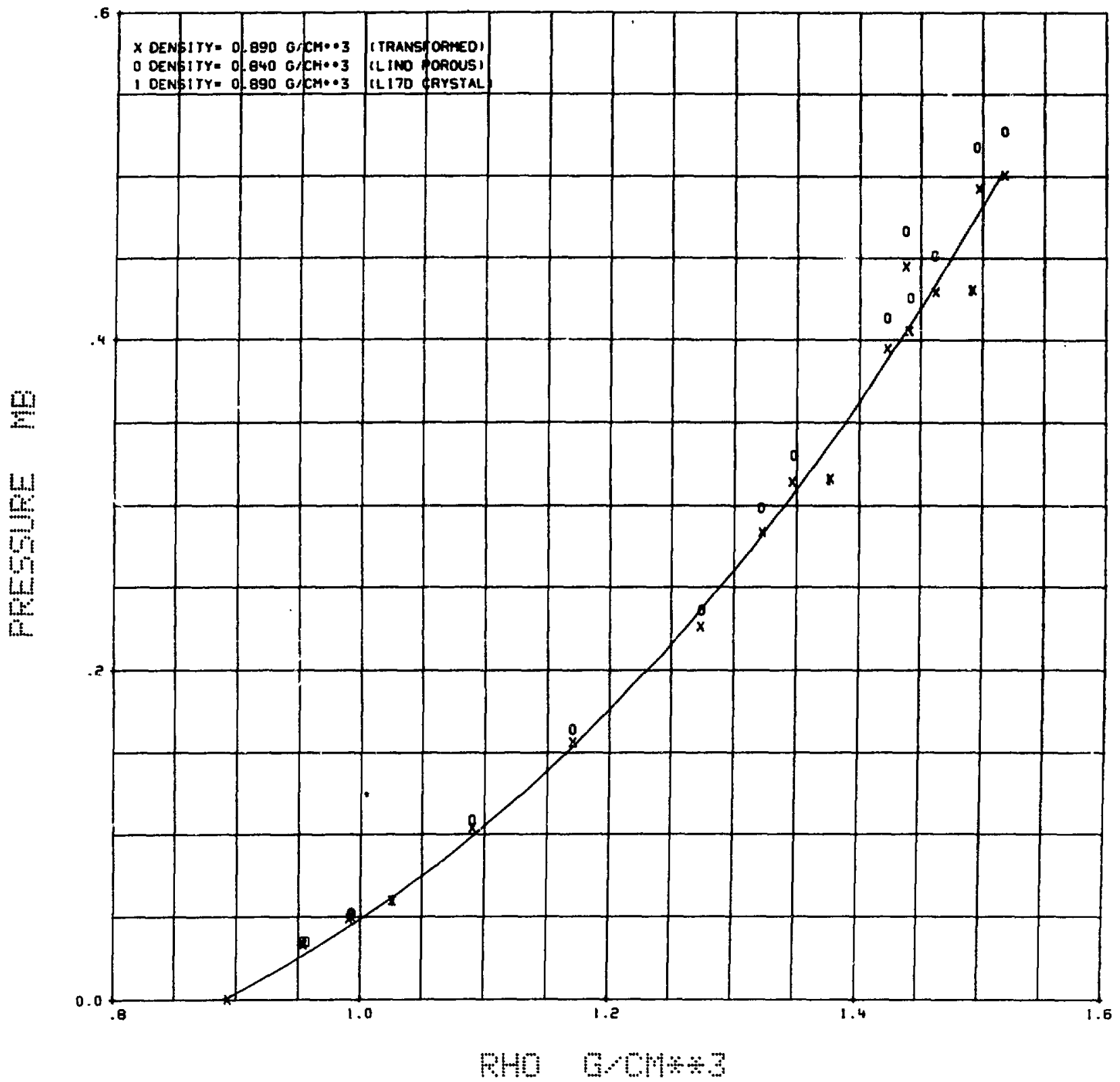

Fig. 10. Pressure-density Hugoniot data for $\mathrm{Li}^{\mathrm{B}} \mathrm{D}$ and $\mathrm{Li}^{7} \mathrm{D}$. Porous Hugoniot data for $\mathrm{Li} \mathrm{i}^{\mathrm{A}} \mathrm{D}$ and experimental single-crystal data for $\mathrm{Li}^{7} \mathrm{D}$ are shown along with transformed crystal-density points. The curve is the fit shown in Fig. 9. 


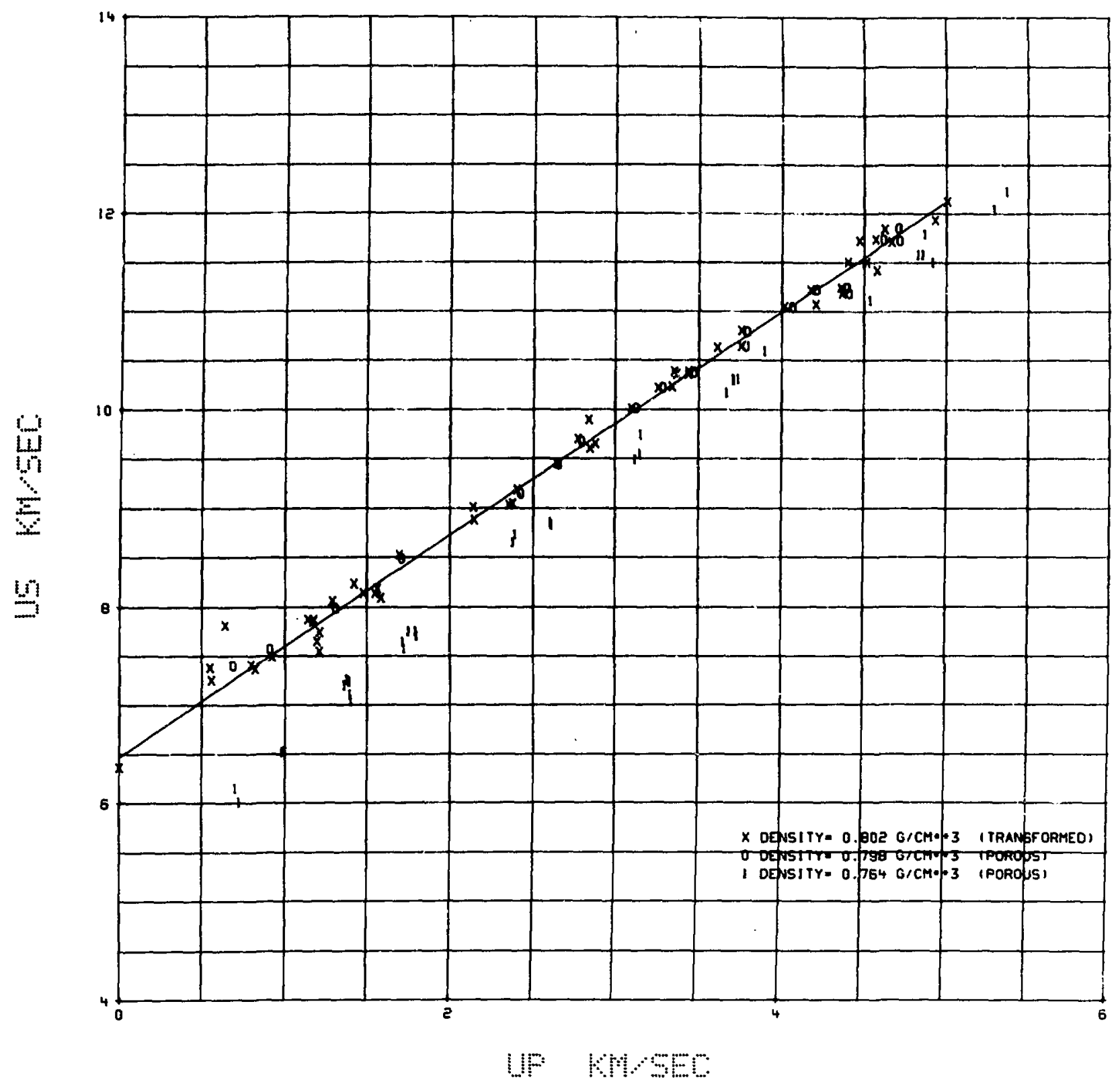

Fig. 11. Shock velocity - particle velocity Hugoniot data for $\mathrm{Li}^{6} \mathrm{D}$. Experimental porous Hugoniot data $\left(\bar{\rho}_{0}=0.798\right.$ and $\left.0.764 \mathrm{~g} / \mathrm{cm}^{3}\right)$ and transformed crystal-density Hugoniot points are shown. A linear least-squares fit of the transformed crystal-density points is shown for points having $\mathrm{U}_{\mathrm{p}}>0.3 \mathrm{~km} / \mathrm{sec}$.

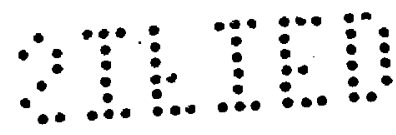




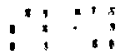

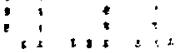

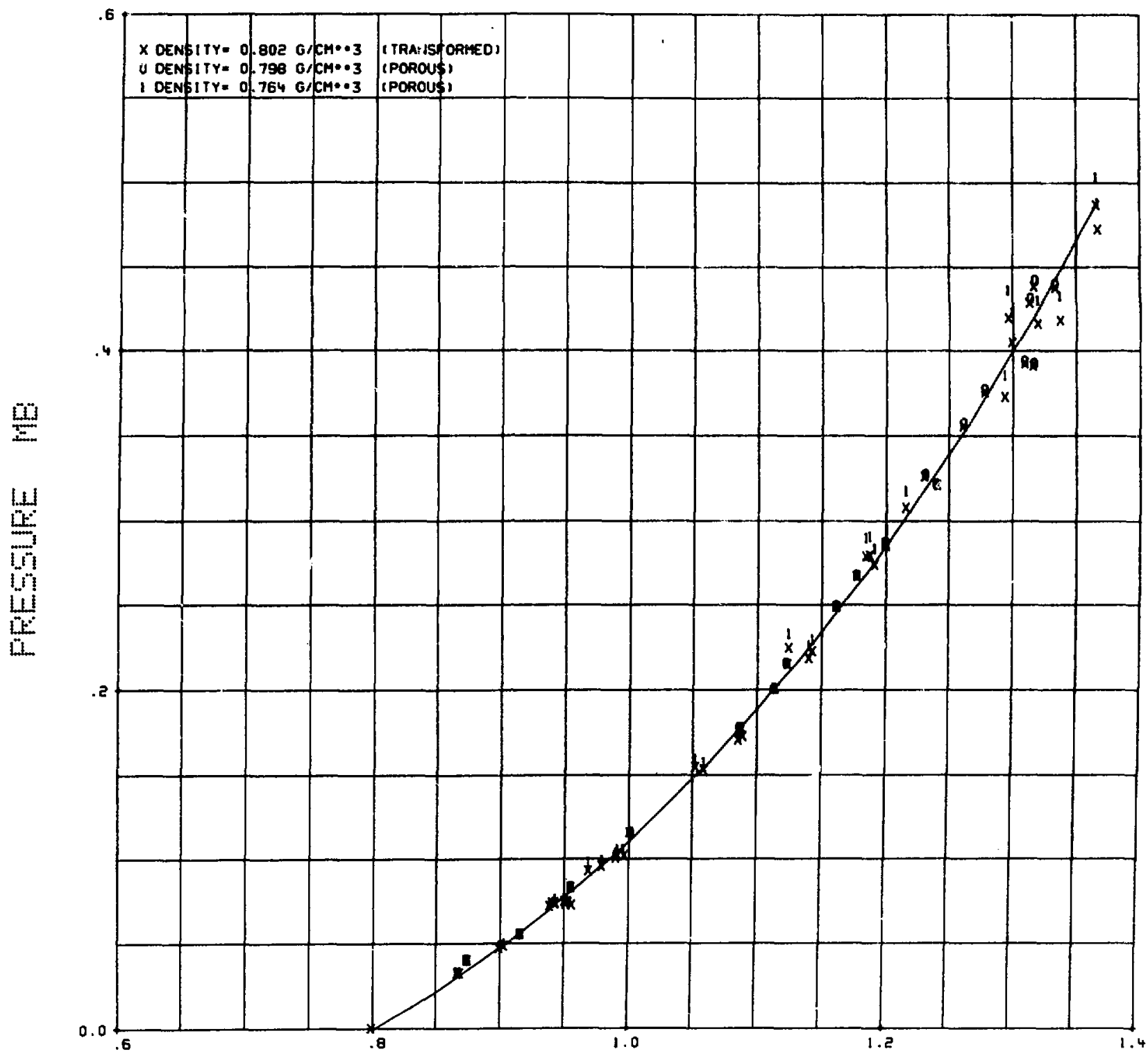

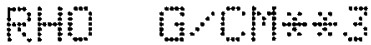

Fig. 12. Pressure-density Hugoniot data for $\mathrm{Li}^{\mathrm{E}} \mathrm{D}$. Experimental porous Hugoniot data $\left(\bar{p}_{0}=0.798\right.$ and $0.764 \mathrm{~g} / \mathrm{cm}^{3}$ ) and transformed crystal-density Hugoniot points are shown. The curve is the fit shown in Fig. 11. 
$\because \because \vdots \vdots "$

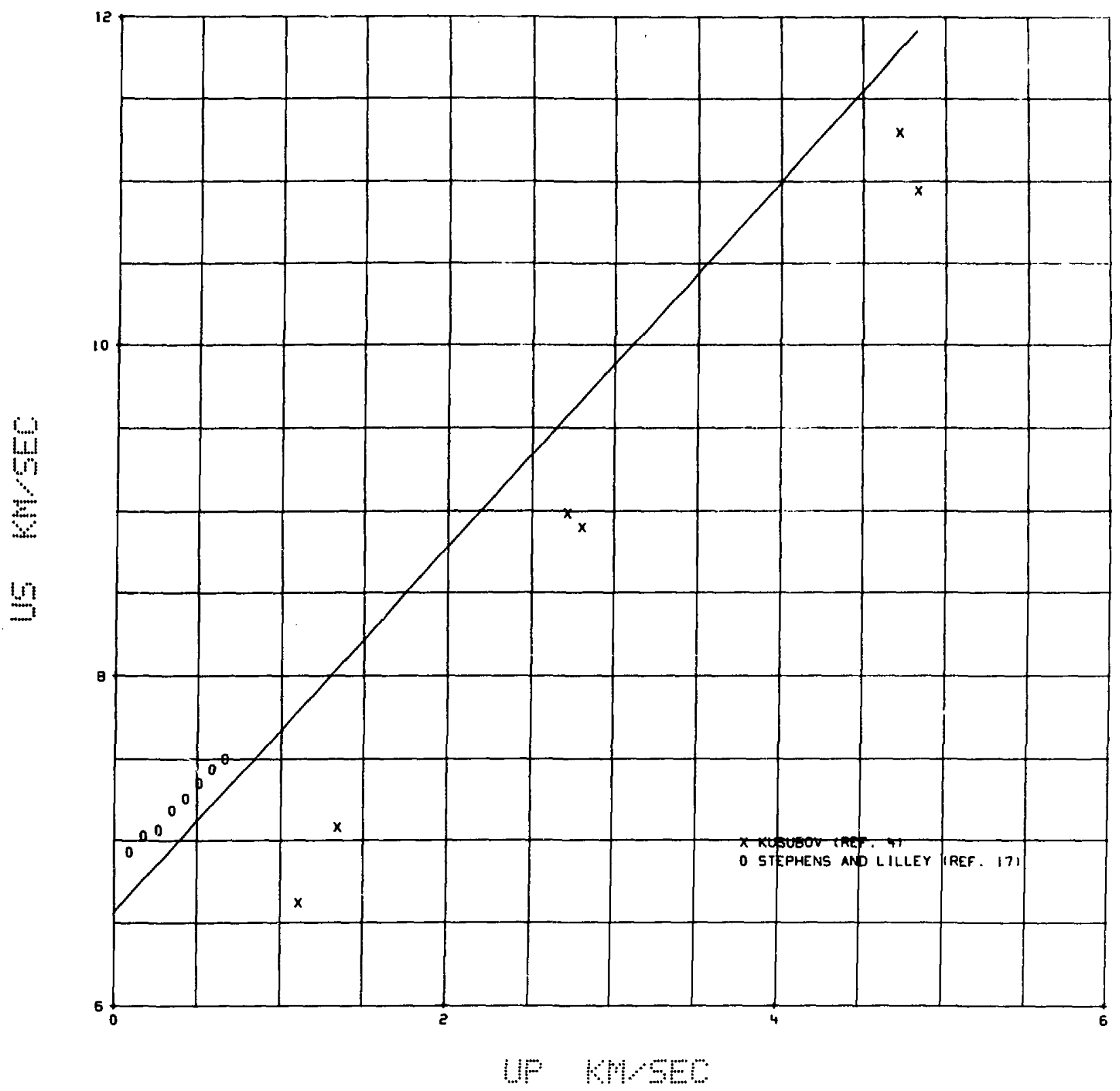

Fig. 13. Summary of other investigators ${ }^{\prime} \mathrm{Li}^{6} \mathrm{H}$ Hugoniot data. The straight line shows the fit reported in Table XV.

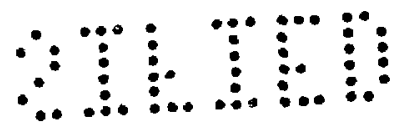




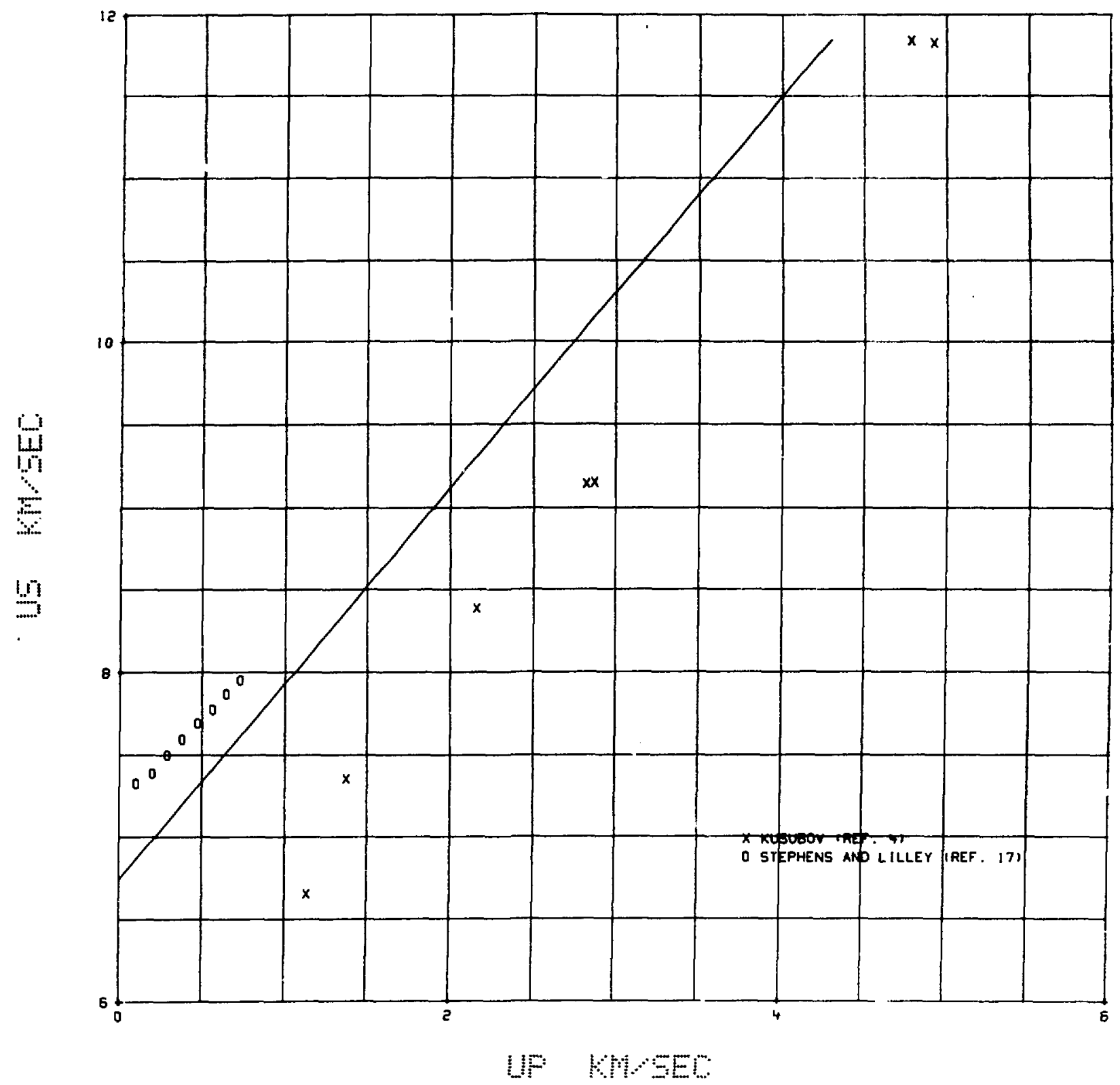

Fig. 14. Summary of other investigators $\mathrm{Li}^{6} \mathrm{D}$ Hugoniot data. The straight line shows the fit reported in Table XV.

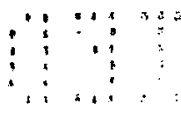

UP $M=$ 


\section{URELARIFIED}
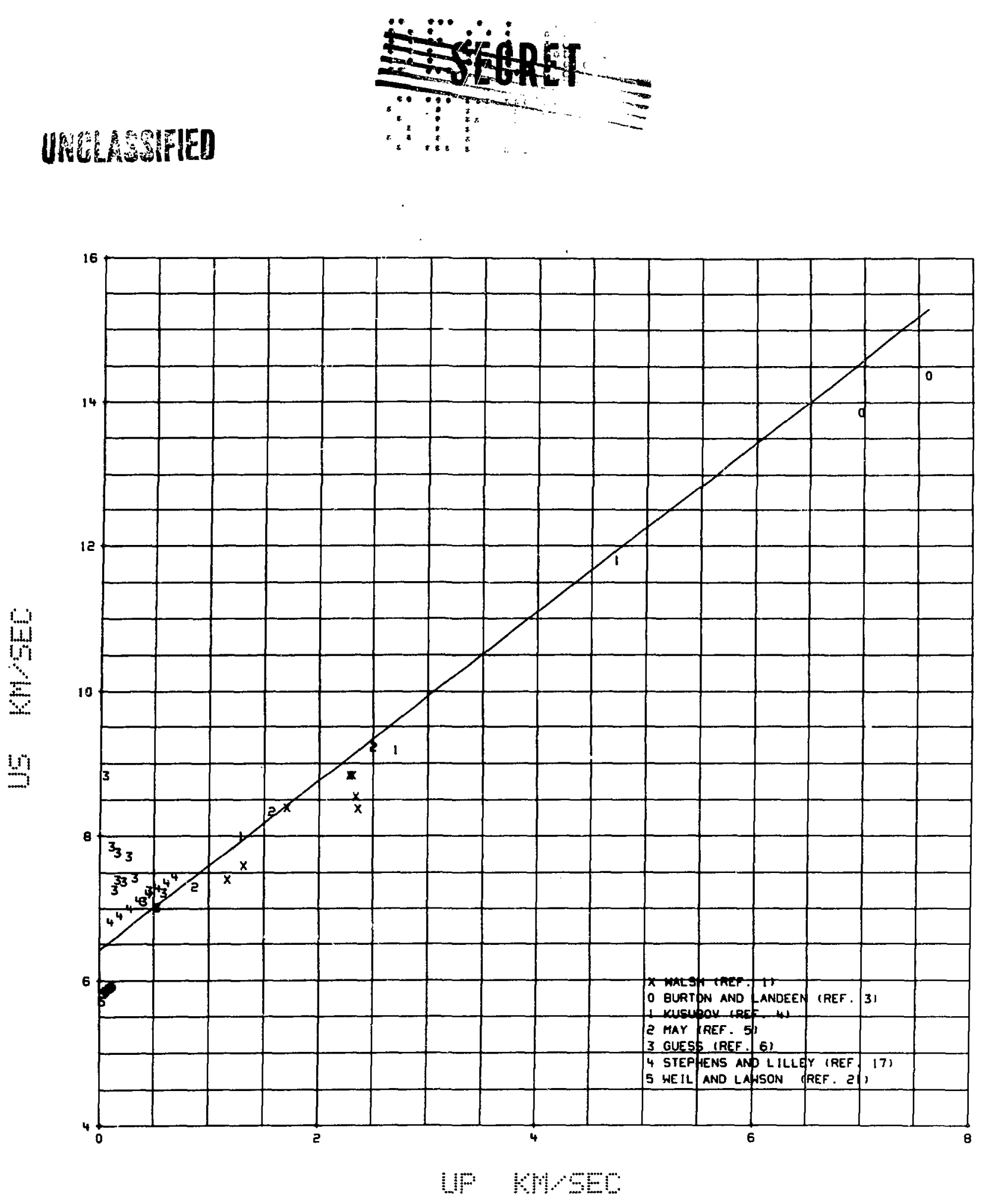

Fig. 15. Summary of other investigators ${ }^{1} \mathrm{Li}^{\mathrm{n}} \mathrm{H}$ Hugoniot data. The straight line shows the fit reported in Table XV.

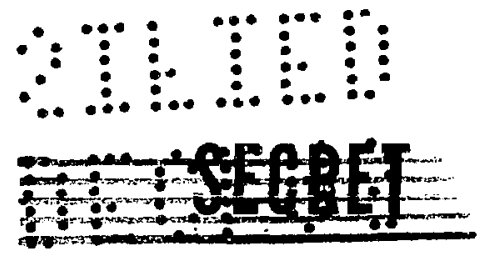




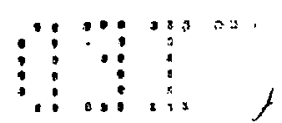

\section{UMELASSFIED}

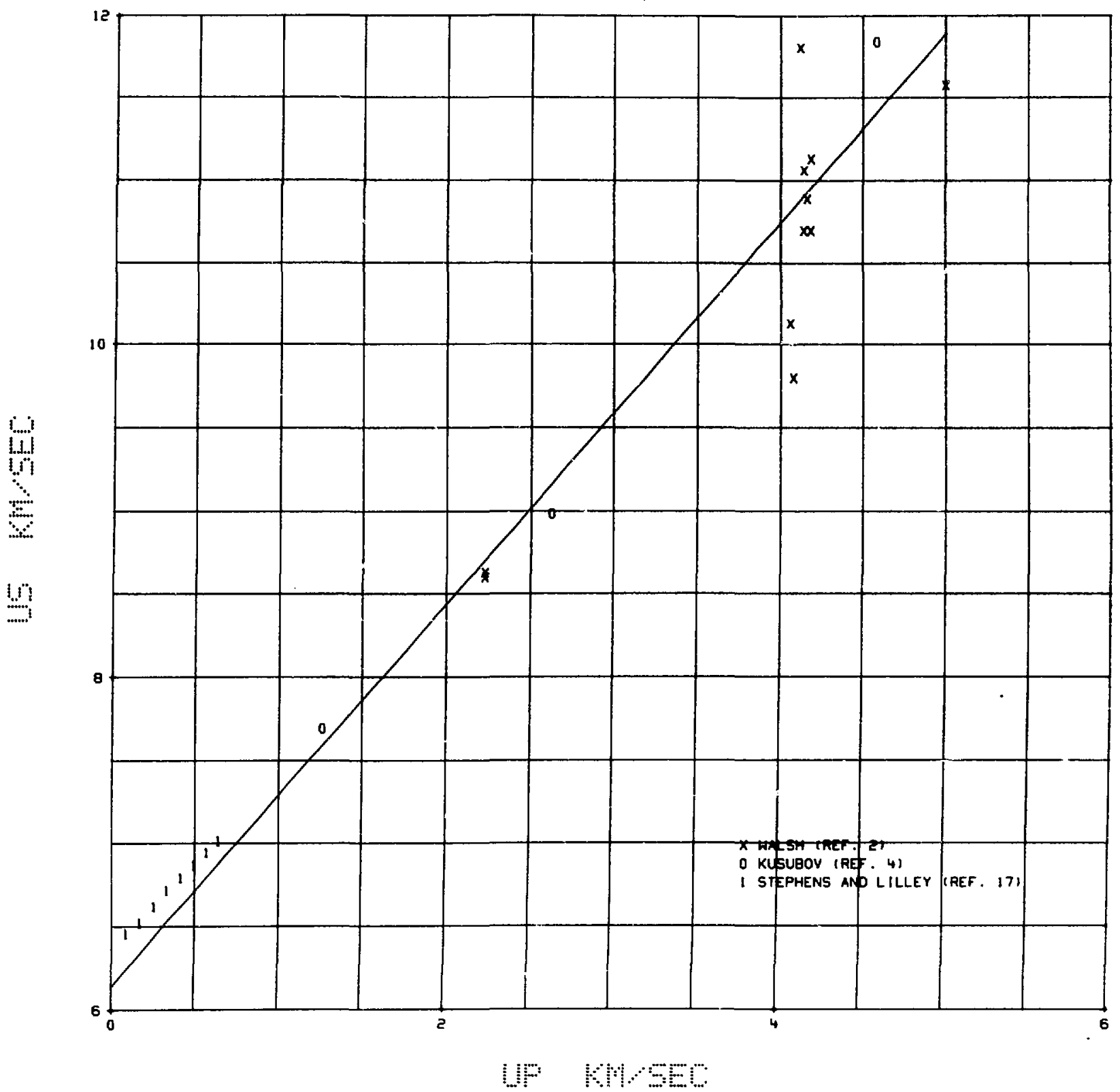

Fig. 16. Summary of other investigators $\mathrm{Li}^{\mathrm{n}} \mathrm{D}$ Hugonio: data. The straight line shows the fit reported in Table XV.

$\mathrm{KT} / \mathrm{rd}: 40$

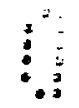

